\title{
A combined field and modeling study of groundwater flow in a tidal marsh
}

\author{
Y. Q. Xia ${ }^{1,2,3}$ and H. L. Li $^{4}$ \\ ${ }^{1}$ Changjiang River Scientific Research Institute (CRSRI), Changjiang Water Resources Commission of the Ministry \\ of Water Resources (CWRC), Wuhan 430010, China \\ ${ }^{2}$ State Key Laboratory of Biogeology and Environmental Geology, China University of Geosciences, Wuhan 430074, China \\ ${ }^{3}$ Center for Natural Resources Development and Protection (NRDP), Department of Civil and Environmental Engineering, \\ Temple University, PA 19122, USA \\ ${ }^{4}$ State Key Laboratory of Biogeology and Environmental Geology, China University of Geosciences-Beijing, \\ Beijing 100083, China
}

Correspondence to: H. L. Li (hailongli@cugb.edu.cn)

Received: 11 May 2011 - Published in Hydrol. Earth Syst. Sci. Discuss.: 24 May 2011

Revised: 11 January 2012 - Accepted: 29 January 2012 - Published: 7 March 2012

\begin{abstract}
Bald mud beaches were found among the mangrove marshes in Dongzhaigang National Nature Reserve, Hainan, China. To investigate the possible reasons for this phenomenon, the intertidal zones of a mangrove transect and a bald beach transect with similar topography and tidal actions were selected for comparison study. Along both transects, observed water table variations were significant in the high and low intertidal zones and negligible in the middle intertidal zones. Despite the same tidal actions and above-mentioned similarities, observed groundwater salinity was significantly smaller along the mangrove transect (average $23.0 \mathrm{ppt}$ ) than along the bald beach transect (average $28.5 \mathrm{ppt}$ ). These observations invite one hypothesis: the hydraulic structure of tidal marsh and freshwater availability may be the main hydrogeological factors critical to mangrove development. Two-dimensional numerical simulations corroborated the speculation and gave results in line with the observed water table. The two transects investigated were found to have a mud-sand two-layered structure: a surface zone of low-permeability mud and an underlying highpermeability zone that outcrops at the high and low tide lines. The freshwater recharge from inland is considerable along the mangrove transect but negligible along the bald beach transect. The high-permeability zone may provide opportunity for the plants in the mangrove marsh to uptake freshwater and oxygen through their roots extending downward into
\end{abstract}

the high-permeability zone, which may help limit the buildup of salt in the root zone caused by evapotranspiration and enhance salt removal, which may further increase the production of marsh grasses and influence their spatial distribution. The bald beach is most probably due to the lack of enough freshwater for generating a brackish beach soil condition essential to mangrove growth. It is also indicated that seawater infiltrated the high-permeability zone through its outcrop near the high intertidal zone, and discharged from the tidal river bank in the vicinity of the low tide line. These processes thereby formed a tide-induced seawater-groundwater circulation, which likely provided considerable contribution to the total submarine groundwater discharge (SGD). Finally, implications and uncertainties behind this study were summarized for future examinations.

\section{Introduction}

Salt marshes perform a variety of functions such as maintaining biodiversity, stabilizing and recycling nutrients and organic carbon (Valiela and Teal, 1979; Steudler and Peterson, 1984; Luther et al., 1986; Dittmar et al., 2006; Kristensen et al., 2008), buffering storms and hurricanes, and providing nursery areas for marine fauna and flora (e.g. Nagelkerken et al., 2008). They have attracted numerous scientific 
investigations, particularly in salt marsh ecology (Chapman, 1938, 1940; Lugo and Snedaker, 1974), which includes many interesting and important issues such as salt marsh dieback and plant zonation (Mendelssohn et al., 1981; Dacey and Howes, 1984; Pennings and Callaway, 1992; Costa et al., 2003; Silvestri et al., 2005; Alber et al., 2008). As one of the most important salt marsh ecosystems, mangrove marshes typically occur along tidal estuaries and coastlines in tropical and subtropical regions (Chapman, 1977; Woodroffe et al., 1985; Kjerfve, 1990; Spalding et al., 1997). They are important for coastal ecology and play an important and irreplaceable role in the maintenance of coastal biodiversity (Field et al., 1998; Bosire et al., 2008). However, mangrove forests are also one of the world's most threatened tropical ecosystems with an obvious global degradation (Valiela et al., 2001; Liu and Diamond, 2005; Duke et al., 2007; Gilman et al., 2008) due to increasing anthropogenic activities such as global warming and sea level rising (Kjerfve, 1990; Duke et al., 1998; Krauss et al., 2008).

Recently a series of discussions on the ecohydrological feedback mechanisms (the linkages between the hydrological cycle, biogeochemical cycling and vegetation dynamics) or ecohydrological interactions were reported by many researchers in salt marshes (Ursino et al., 2004; Li et al., 2005; Marani et al., 2005, 2006; Wilson and Gardner, 2005; Gardner, 2009; Tossatto et al., 2009; Chui et al., 2011) and in riverine and island systems (Bauer et al., 2006; BauerGottwein et al., 2008). In particular, Marani et al. (2006) linked the complex spatial patterns of vegetation to the relevant hydrological and ecological processes in oxygen-limited tidal marsh ecosystems by a model of coupling hydrogeomorphic and ecological dynamics. They found that the ecohydrological interactions contribute the patterns of vegetation colonization and spatial zonation, which especially highlighted the roles of hydraulic conductivity and evapotranspiration in aerating the soils of tidal marshes. Ursino et al. (2004) and Marani et al. (2006) stated that the presence of a zone of aerated soil beneath the marsh surface could have profound implications for marsh ecology. However, Gardner (2009) pointed out that it would be true only if the subsurface air contains a permanent and significant concentration of oxygen for use in respiration and/or oxidation of organic matter. Bauer et al. (2006) and Bauer-Gottwein et al. (2008) presented the quantifications and modeling of ecohydrological feedback mechanisms (e.g. phytotoxicity, transpiration stream concentration factor) in semi-arid and arid regions (e.g. riverine and island systems). They concluded that precipitation and evapotranspiration are important processes in such systems and contribute significantly to the water balance and salt accumulation.

Freshwater is important for controlling the salinity and nutrient transport in mangrove tidal marshes around the world. Kjerfve (1990) reported that the input of freshwater is ultimately responsible for creation of the brackish to saline coastal wetland environment where mangrove thrives. Nuttle and Harvey (1995) reported the effects of the upward discharge of fresh groundwater on the water and solute movements within an intertidal wetland on Virginia's Atlantic coast. They found that groundwater-driven advection prevents infiltration of brackish water during tidal flooding and removes solutes from the sediment of the wetland. Selvam (2003) examined the variations in the periodicity and quantity of freshwater flowing into mangrove wetlands in India, and found that the reduction in freshwater flow would lead to reduction in the diversity of exclusive mangrove plant species. Montalto et al. (2006) presented the hydrological characteristics of the Piermont Marsh in the Hudson River Estuary, New York, USA. They concluded that the hydraulic properties largely influence the ecological functions of marsh and determine the groundwater discharge rate from the marsh to the estuary. Schwendenmann et al. (2006) found that the sediment permeability and freshwater input had a strong effect on the solute dynamics (e.g. salt content) in tidal creek and mangrove water and on the vertical distribution in the sediment in a mangrove in North Brazil (Furo do Meio, Para). Acting as a main carrier of salt and nutrients, groundwater flow plays a significant role in the mass fluxes across the sediment-water interface and therefore affects the tidal marsh ecological system (Hemond and Fifield, 1982; Howes et al., 1996; Gardner, 2005; Wilson and Gardner, 2006; Akamatsu et al., 2009).

In many tidal marsh systems in the world, highpermeability zones were found under the surface marsh mud and they usually consist of sands or sandy loam (e.g. Harvey et al., 1987; Hughes et al., 1998; Gardner and Porter, 2001; Xin et al., 2009). Gardner and Porter (2001) reported that marsh mud commonly overlies a sand layer in the southeastern United States. Schwendenmann et al. (2006) also found that the hydraulic conductivity of deeper fine sand strata in a mangrove in North Brazil was 7 to 18 times larger than that $\left(<0.1 \mathrm{~m} \mathrm{day}^{-1}\right)$ of the upper mud layer. Gardner (2007) noted that the presence of the sand layer beneath marsh mud is likely to increase seepage from marsh soils and enhances lowering of the water table and thereby increases aeration throughout the marsh. This kind of high-permeability zones might also contribute to the creation of a preferentially aerated layer under the plant roots (Tossatto et al., 2009).

In Dongzhaigang National Nature Reserve, Hainan Island, China, most mangroves are distributed along the broad shallow beach such as Sanjiang plain and the coastal area of Tashi (Fig. 1a); other mangrove forests are situated along rivers (e.g. Yanfeng River, Fig. 1b). However, bald beaches without any vegetation were found among mangrove marshes. In order to investigate the hydrogeological factors critical to mangrove development, a mangrove transect and bald beach transect were selected to conduct comparison study (Fig. 1b). The mangrove transect is located in the Changningtou tidal marsh, and adjacent to the estuary of Yanfeng River. The bald beach transect is situated in a tidal beach without any vegetation and abuts the Shanweitou Village and 


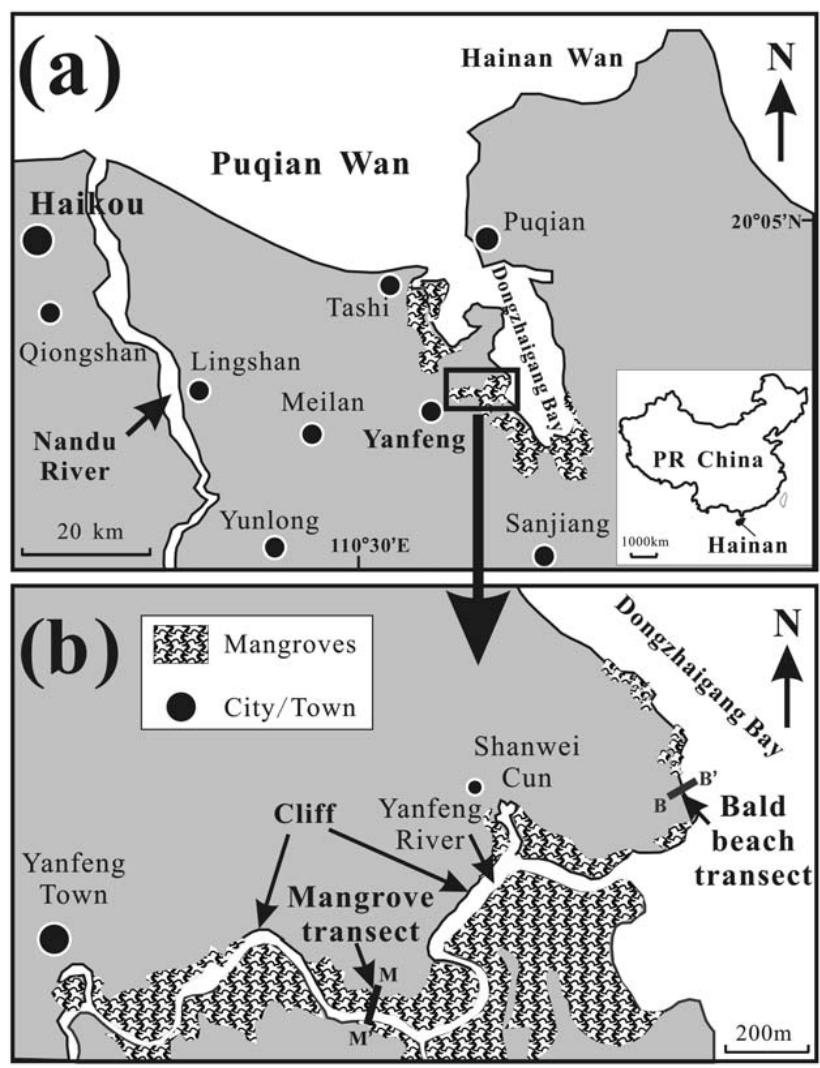

Fig. 1. Location maps of (a) Dongzhaigang National Nature Reserve (DNNR), China and (b) the mangrove transect $\mathrm{M}-\mathrm{M}^{\prime}$ and the bald beach transect B-B'.

Dongzhaigang Bay. Along each transect, eight or nine observation wells were installed, and the water level and salinity in the wells were measured for three days with intervals of $1 \sim 3 \mathrm{~h}$. Based on the observations, the following hypothesis is proposed: the hydraulic structure of tidal marsh and freshwater availability may be the main hydrogeological factors critical to mangrove development. The finite element model MARUN (MARine UNsaturated, Boufadel et al., 1999) was used to corroborate the observations for hypothesis testing. Ecohydrological implications were carefully discussed by relating to the observations and modeling results such as seawater-groundwater interaction, beach permeability distribution, marsh soil aeration conditions, marsh plant zonation, freshwater recharge from inland, and submarine groundwater discharge (SGD).

\section{Study sites}

Dongzhaigang National Nature Reserve, a subtropical tidal wetland with curved coastlines and gentle harbors, is the first mangrove forest reserve in China, founded in 1980 and located in north-eastern Hainan Island, about $32 \mathrm{~km}$ from Haikou City. Its geographical coordinates are $19^{\circ} 57^{\prime}-20^{\circ} 01^{\prime} \mathrm{N}, 110^{\circ} 32^{\prime}-110^{\circ} 37^{\prime} \mathrm{E}$ (Fig. 1a). Tides in this area are a mixture of diurnal and semidiurnal components. The tidal range is about $1.92 \mathrm{~m}$ during spring tides and $0.38 \mathrm{~m}$ during neap tides (NMDIS, 2008). Dongzhaigang is a shallow water bay formed by continental sink during the 1605 Great Qiongzhou Earthquake, and has a typical subtropical monsoon marine climate. With $2065 \mathrm{~km}^{2}$ of mangrove forests distributed in the shoals of the tidal zone, Dongzhaigang National Nature Reserve accounts for $44.51 \%$ of mangrove forests of Hainan Island and is the largest mangrove forest nature reserve in China, holds the most abundant mangrove species, and has been giving the best preservation. Its annual average rainfall range is 1700$1933 \mathrm{~mm}$ (data during 1973-1986) with $80 \%$ of the precipitation occurring during May-October. The annual average temperature of the surface sea water is $24.5^{\circ} \mathrm{C}$ ( $\left.\mathrm{Fu}, 1995\right)$. The mangrove marshes in Dongzhaigang National Nature Reserve mainly distribute in three coastal areas: Tashi, Yanfeng and Sanjiang Plain (Fig. 1a).

Two transects were selected for field investigations in Yanfeng and their distance is about $1.8 \mathrm{~km}$ (Fig. 1b). The first (mangrove transect) is located in Changningtou mangrove tidal marsh, and adjacent to the estuary of Yanfeng River. Mangrove plant species at this site mainly include Aegiceras corniculatum, Bruguiera sexangula, Bruguiera gymnorrhiza, Kadelia candel, Ceriops tagal and Acanthus ilicifolius (Ye and Lu, 2001). Nine monitoring wells (M0M8) were installed along the mangrove transect $\left(M-M^{\prime}\right.$ in Figs. 1b, 2a) perpendicular to the high tide mark. Well M0 is located at the intersection of mangrove marsh and inland hill. The width of intertidal zone is about $100 \mathrm{~m}$ (Fig. 2a). The second (bald beach transect) is situated in a tidal beach without any vegetation. It abuts the Shanweitou Village and Dongzhaigang Bay. The beach sediment is mainly mud. Eight monitoring wells (B0-B7) were set up in the bald beach transect perpendicular to the high tide mark (B-B' in Figs. 1b, 2b). The width of intertidal zone is about $190 \mathrm{~m}$ (Fig. 2b). When choosing the mangrove transect, several important factors besides the distance between the two transects were comprehensively considered, e.g. logistic conveniences, human activities around the transect, and approval from the local administration. Although the present location of $\mathrm{M}$ would weaken the comparative study between the mangroves and bald beaches and there are other mangrove transects closer to the bald beach transect, we were not allowed to conduct a field study there by one or more of these factors.

\section{Methods}

\subsection{Borehole drilling}

Boreholes were drilled with hand augers (AMS Inc., USA) to install observation wells. The depths of the boreholes are $2.0 \mathrm{~m}$ in intertidal zones of both transects and $4.0 \mathrm{~m}$ landward 

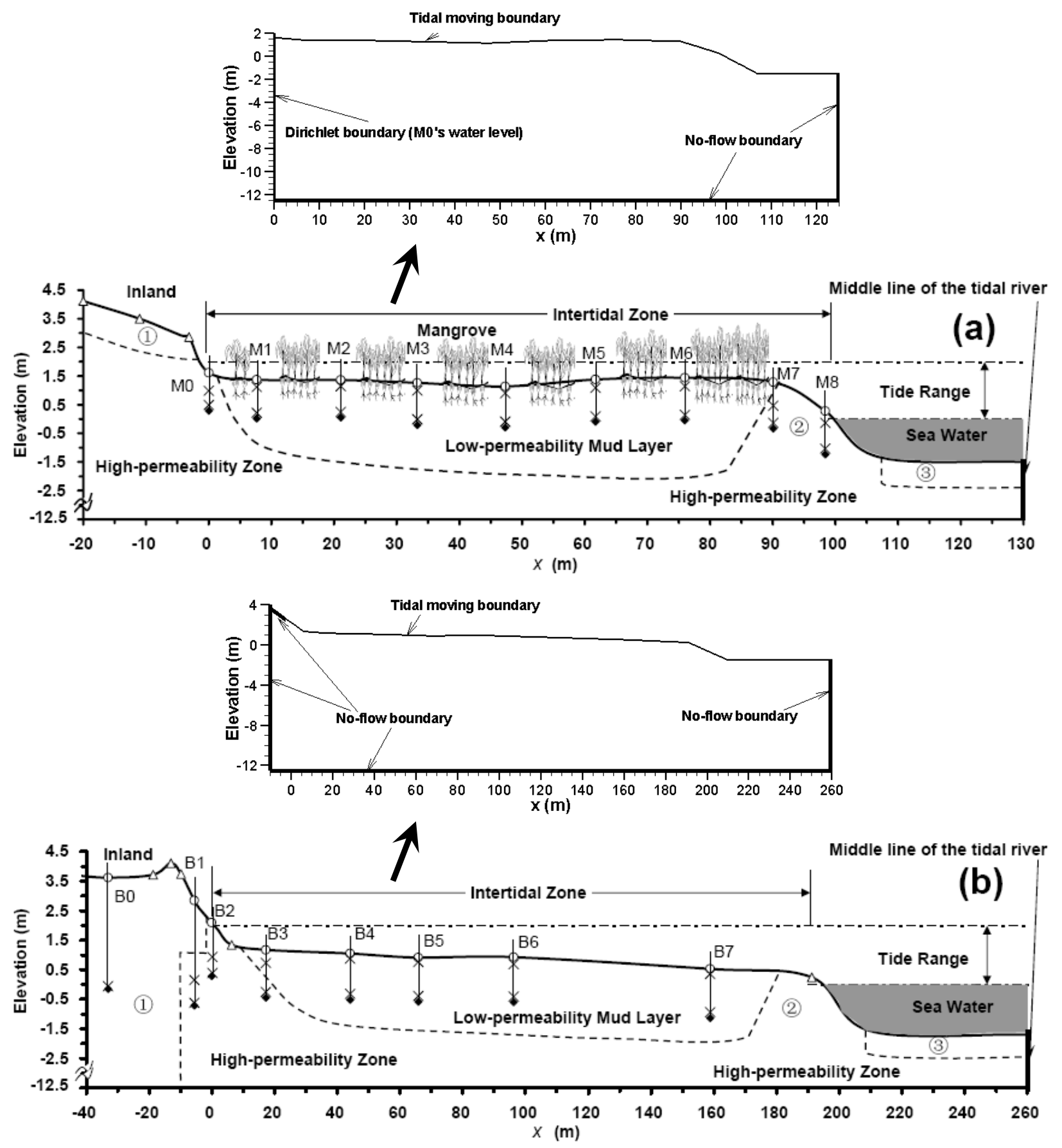

\footnotetext{
$\circ$ Observation well $\Delta$ Ground surface elevation measurement point $\quad \times$ Salinity measurement location $\bullet$ Well bottom

. . . . Location of the interface between the low-permeablity marsh soil and underlain high-permeability zone

Beach surface (1) Low-permeability inland soil (2) Loose bank zone (3) Low-permeability creek bed sediment
}

Fig. 2. The cross-section of (a) the mangrove transect $M-\mathrm{M}^{\prime}$ and (b) the bald beach transect $\mathrm{B}-\mathrm{B}^{\prime}$. The intertidal zone is located within $0 \mathrm{~m} \leq x \leq 100 \mathrm{~m}$ for the mangrove transect and $0 \mathrm{~m} \leq x \leq 190 \mathrm{~m}$ for the bald beach transect, where $x$ is the seaward distance from the high tide mark. The detailed information about monitoring wells is presented in Fig. 3 and Tables 1 and 2. The conceptual hydrological models of both transects are also shown in this figure. 
Table 1. Locations and depths of wells at the mangrove transect $\mathrm{M}-\mathrm{M}^{\prime}$.

\begin{tabular}{|c|c|c|c|c|c|c|c|}
\hline \multirow[t]{2}{*}{ Locations } & \multirow{2}{*}{$\begin{array}{r}\text { Distance } \\
(\mathrm{m})\end{array}$} & \multirow{2}{*}{$\begin{array}{r}\text { Elevation } \\
(\mathrm{m})\end{array}$} & \multirow{2}{*}{$\begin{array}{r}\text { Well } \\
\text { length above } \\
\text { surface }(\mathrm{m})\end{array}$} & \multirow{2}{*}{$\begin{array}{r}\text { Well } \\
\text { length below } \\
\text { surface }(\mathrm{m})\end{array}$} & \multicolumn{2}{|c|}{$\begin{array}{c}\text { Elevations of salinity } \\
\text { measurement }(\mathrm{m})\end{array}$} & \multirow{2}{*}{$\begin{array}{r}\text { Thickness } \\
\text { of mud } \\
\text { layer }(\mathrm{m})\end{array}$} \\
\hline & & & & & Shallow & Deep & \\
\hline M0 & 0.000 & 1.615 & 0.67 & 1.33 & 0.985 & 0.485 & 0.8 \\
\hline$* * \mathrm{M}^{*} 1$ & 1.038 & 1.582 & -* & - & - & - & 1.0 \\
\hline M1 & 7.679 & 1.367 & 0.65 & 1.35 & 1.117 & 0.217 & 2.5 \\
\hline M2 & 21.081 & 1.366 & 0.68 & 1.32 & 1.146 & 0.246 & 2.5 \\
\hline M3 & 33.291 & 1.259 & 0.53 & 1.47 & 0.989 & -0.011 & 2.6 \\
\hline M4 & 47.331 & 1.133 & 0.57 & 1.43 & 0.903 & -0.097 & 3.0 \\
\hline M5 & 61.719 & 1.375 & 0.52 & 1.48 & 1.095 & 0.095 & 3.5 \\
\hline M6 & 75.985 & 1.435 & 0.51 & 1.49 & 1.145 & 0.145 & 3.7 \\
\hline M7 & 90.096 & 1.284 & 0.38 & 1.62 & 0.464 & -0.136 & 0.4 \\
\hline M8 & 98.378 & 0.273 & 0.49 & 1.51 & -0.137 & -1.037 & 0.0 \\
\hline$M * 2$ & 107.0 & -1.5 & - & - & - & - & 1.0 \\
\hline$M * 3$ & 130.0 & -1.5 & - & - & - & - & 1.0 \\
\hline
\end{tabular}

* “_" means not available. ** $\mathrm{M}^{*} 1, \mathrm{M}^{*} 2$, and $\mathrm{M} * 3$ are only used to control the geometry of the surface and interfaces, no wells were installed at these locations.

Table 2. Locations and depths of wells at the bald beach transect B-B'.

\begin{tabular}{|c|c|c|c|c|c|c|c|}
\hline \multirow[t]{2}{*}{ Locations } & \multirow{2}{*}{$\begin{array}{r}\text { Distance } \\
(\mathrm{m})\end{array}$} & \multirow{2}{*}{$\begin{array}{r}\text { Elevation } \\
(\mathrm{m})\end{array}$} & \multirow{2}{*}{$\begin{array}{r}\text { Well } \\
\text { length above } \\
\text { surface }(\mathrm{m})\end{array}$} & \multirow{2}{*}{$\begin{array}{r}\text { Well } \\
\text { length below } \\
\text { surface }(\mathrm{m})\end{array}$} & \multicolumn{2}{|c|}{$\begin{array}{c}\text { Elevations of salinity } \\
\text { measurement }(\mathrm{m})\end{array}$} & \multirow{2}{*}{$\begin{array}{r}\text { Thickness } \\
\text { of mud } \\
\text { layer }(\mathrm{m})\end{array}$} \\
\hline & & & & & Shallow & Deep & \\
\hline B0 & -33000 & 3.611 & 0.23 & 3.77 & $-^{*}$ & -0.059 & - \\
\hline${ }^{* *} \mathrm{~B}_{\mathrm{LB}}$ & -10000 & 3.737 & - & - & - & - & 0.0 \\
\hline B1 & -5.568 & 2.839 & 0.44 & 3.56 & 0.149 & -0.621 & 2.0 \\
\hline B2 & 0.000 & 2.094 & 0.19 & 1.81 & 1.112 & 0.562 & 0.0 \\
\hline $\mathrm{B} * 1$ & 6.369 & 1.337 & - & - & - & - & 0.0 \\
\hline B3 & 17.284 & 1.166 & 0.38 & 1.62 & 0.726 & -0.254 & 0.9 \\
\hline $\mathrm{B} * 2$ & 26.082 & 1.127 & - & - & - & - & 2.0 \\
\hline B4 & 44.078 & 1.048 & 0.43 & 1.57 & 0.878 & -0.322 & 2.5 \\
\hline B5 & 65.835 & 0.907 & 0.50 & 1.50 & 0.757 & -0.393 & 2.5 \\
\hline B6 & 96.196 & 0.921 & 0.47 & 1.53 & 0.691 & -0.409 & 2.5 \\
\hline B7 & 158.884 & 0.527 & 0.33 & 1.67 & 0.357 & -0.943 & 2.5 \\
\hline $\mathrm{B} * 3$ & 191.263 & 0.237 & - & - & - & - & 0.0 \\
\hline$B * 4$ & 210.0 & -1.5 & - & - & - & - & 1.0 \\
\hline $\mathrm{B} * 5$ & 260.0 & -1.5 & - & - & - & - & 1.0 \\
\hline
\end{tabular}

* “-” means not available. ${ }^{* *} \mathrm{~B}_{\mathrm{LB}}$ denotes the landward boundary location, $\mathrm{B} * 1, \mathrm{~B} * 2, \mathrm{~B} * 3, \mathrm{~B} * 4$, and $\mathrm{B} * 5$ are only used to control the geometry of the surface and interfaces, no wells were installed at these locations.

of the high tide mark of the bald beach transect. Landward of the high tide mark of the mangrove transect, only very shallow boreholes could be drilled with hand augers due to hard rocks encountered below the thin $(0.5 \sim 0.8 \mathrm{~m})$ soil cover. A $1.0 \mathrm{~m}$ wide and $1.0 \mathrm{~m}$ long pit was excavated there and volcanic basalt boulders were found below the thin soil cover, which prevented us from further excavating to find the inland water table.

\subsection{Well construct and installations}

Each well was made up of inner and outer PVC pipes (Fig. 3). The diameter of the outer pipe was $5 \mathrm{~cm}$ and that of the inner pipe $3.8 \mathrm{~cm}$. Holes with diameter of $5.0 \mathrm{~mm}$ were drilled evenly around the perimeters of the inner and outer PVC pipes with a density of $4 \sim 5$ holes per $5 \mathrm{~cm}$ of the pipe's longitudinal length. Then outer and inner pipes were wrapped by fine plastic screen, and the inner pipe was put inside the outer one (Fig. 3). The space between the two pipes was filled with coarse sands $(0.5 \mathrm{~mm} \sim 2 \mathrm{~mm}$ in diameter $)$. When installing the well, the space between the borehole and the 


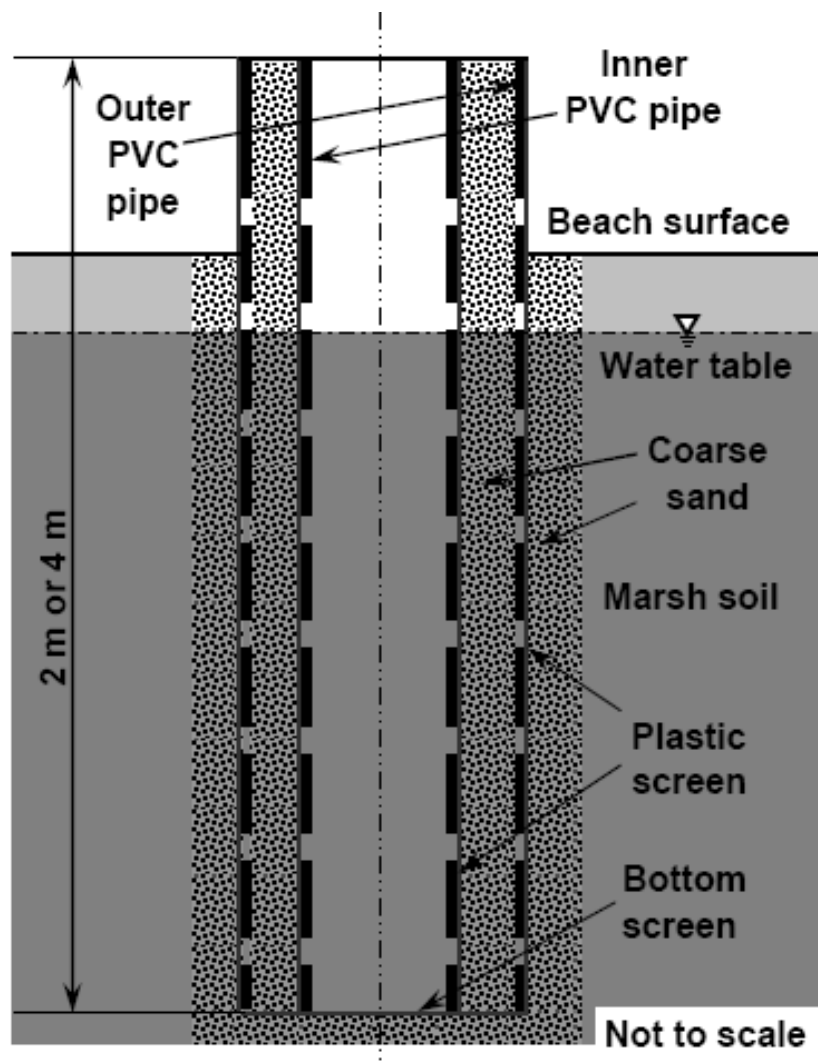

Fig. 3. Installation details of the observation wells.

outer pipe was also filled with the same coarse sands. All these measures were taken in order to prevent the fine beach sediments from entering wells and to guarantee good hydraulic connection between the beach groundwater and the water inside the well. All the monitoring wells were installed during 12-17 December 2007, which provided $7 \sim 13$ days for the disturbed groundwater level and salinity profiles to recover to natural status. The elevations of wells and the topography of study profiles were geometrically leveled using Electronic Total Station (TOPCON, Japan) which has a measurement accuracy of $\pm 2 \mathrm{~mm}$. The data are summarized in Tables 1 and 2.

\subsection{Field measurements}

Water level and salinity in each well were measured respective by using an electronic dipper system and the Salinity Handheld meter (JENCO Inc., USA) for a 3-day period from 25 December 2007, 08:00 LT to 28 December 2007, 08:00 LT.

\section{Field results}

Our field observations were conducted during spring tides. There was no rainfall during the 3-day observation period.
The tidal level $\left(H_{\text {Tide }}\right)$ is represented by the following analytical expression:

$H_{\text {Tide }}(t)=h_{\mathrm{MSL}}+\sum_{i=1}^{5} A_{i} \cos \left(\omega_{i} t+\varphi_{i}\right)$,

where $h_{\mathrm{MSL}}$ denotes the mean sea level, and $A_{i}, \omega_{i}$ and $\varphi_{i}$ $(i=1, \cdots, 5)$ are the amplitude $(\mathrm{m})$, frequency $\left(\mathrm{rad} \mathrm{h}^{-1}\right)$ and phase shift (rad) of the $i$-th component of tides, respectively (their values are listed in Table 3). They were obtained using the least-squares fitting to the water table observed at the seaward wells at the beach (well M8 for the mangrove transect and B7 for the bald beach) when the surface of these wells were submerged. After the tidal levels were determined, the lowest tidal level in each transect was defined as the elevation datum there $(z=0$, Fig. 2$)$. Here we used five harmonic tidal components $(\mathrm{O} 1, \mathrm{~K} 1, \mathrm{M} 2, \mathrm{~S} 2$, and $\mathrm{N} 2$, see Table 3) because they are important geophysically, together accounting for approximately $95 \%$ of the total tidal potential (Merritt, 2004).

The observed time series of water levels and groundwater salinity along the two transects are reported in Fig. 4 together with the ground surface elevation and the analytical fitting of the tidal level. During high tides, the seawater was too deep at some wells in the middle and lower intertidal zone (such as M5-M8, and B3-B7) for these wells to be accessed, thus the measurements happened during only low tides. Water table variation patterns along the mangrove transect could be classified into two groups (Fig. 4a): (1) quick dropping of water table during low tides and abrupt rising when the ground surface at the well was submerged by rising tides (M0 and M7); (2) very slow or negligible dropping of water table during low tides (M1-M6, and M8). Water table variation patterns along the bald beach could be classified into four groups (Fig. 4b): (1) B0: slight daily fluctuation (amplitude smaller than $0.1 \mathrm{~m}$ ) around a very low elevation slightly higher than the lowest tidal level $(z=0 \mathrm{~m})$; (2) B1-B3: quick dropping of water table during low tides and abrupt rising when the ground surface at the well was submerged by rising tides; (3) B6: mild dropping of water table during low tides and quick rising when the ground surface at the well was submerged by rising tides; and (4) the remainders (B4, B5, and B7): very slow or negligible dropping of water table during low tides.

Along the mangrove transect (Fig. 4a), low salinities were observed at (1) both shallow and deep depths of M0 during low and rising tides, (2) both shallow and deep depths of M8 during low tides, particularly at shallow depths of M8, and (3) at shallow depths of M1, M2 and M3 during rising and high tides. Along the bald beach transect (Fig. 4b), exceptionally low and almost constant salinities (about $5 \mathrm{ppt}$ ) were observed at B0. At other wells, the observed salinities remained high $(25 \sim 30 \mathrm{ppt})$ and did not show much variation with respect to depth or time (tidal level).

Soil samples with $8 \mathrm{~cm}$ length and $7 \mathrm{~cm}$ diameter were collected at an interval of $5 \mathrm{~cm}$ during well installation and 

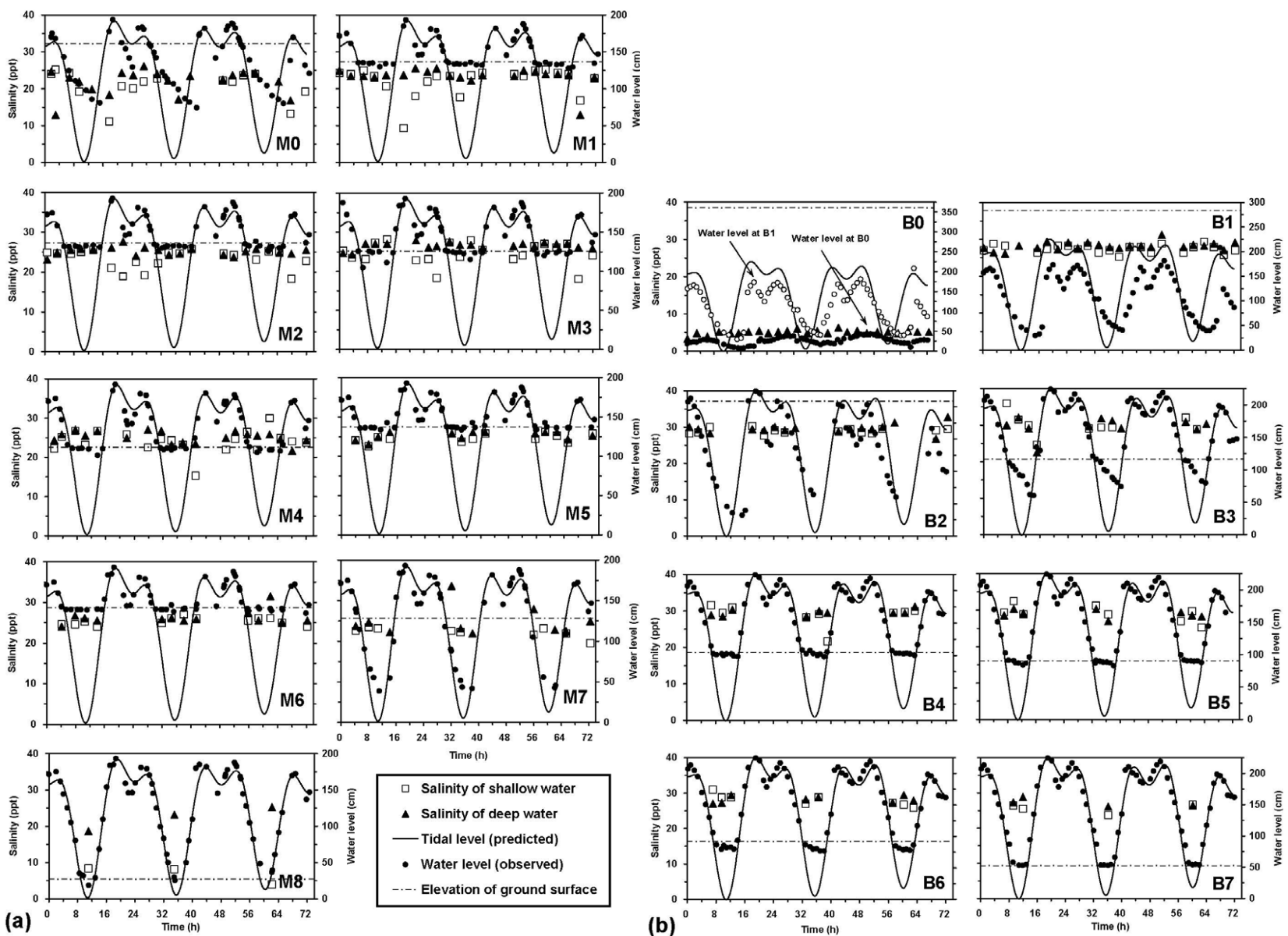

Fig. 4. Observed salinity (ppt) of groundwater and water level in monitoring wells along (a) mangrove transect $\mathbf{M - M ^ { \prime }}$ and (b) bald beach transect B-B'. The initial time of zero hour corresponds to 25 December 2007, 08:00 LT. The square symbols are the salinity of the groundwater at shallow location in the well, and the black triangle symbols are the salinity of the groundwater at deep location in the well. The shallow and deep locations for each well were indicated in Fig. 2 and given in Tables 1 and 2. The filled circles are observed water level. The ground surface elevation (thin dash-dot line) at each well and the tidal level (thick line) are also shown. For convenience of comparison, observed water table at B1 was also shown in empty circles in the panel for B0.

Table 3. Fitting results of sea tides.

\begin{tabular}{|c|c|c|c|c|c|c|}
\hline \multicolumn{4}{|c|}{ Mangrove transect } & \multicolumn{3}{|c|}{ Bald beach transect } \\
\hline $\begin{array}{l}\text { Mea sea level } \\
h_{\mathrm{MSL}}(\mathrm{m})\end{array}$ & Component ${ }^{*} i$ & $\begin{array}{r}\text { Amplitude } \\
A_{i}(\mathrm{~m})\end{array}$ & $\begin{array}{r}\text { Phase shift } \\
\phi_{i}(\mathrm{rad})\end{array}$ & $\begin{array}{r}\text { Mea sea level } \\
h_{\mathrm{MSL}}(\mathrm{m})\end{array}$ & $\begin{array}{r}\text { Amplitude } \\
A_{i}(\mathrm{~m})\end{array}$ & $\begin{array}{r}\text { Phase shift } \\
\phi_{i}(\mathrm{rad})\end{array}$ \\
\hline \multirow{5}{*}{1.211} & $1(\mathrm{O} 1)$ & 0.505 & 0.576 & \multirow{5}{*}{1.181} & 0.598 & 0.404 \\
\hline & 2 (K1) & 0.315 & 0.564 & & 0.432 & 0.689 \\
\hline & 3 (M2) & 0.543 & -2.562 & & 0.429 & -2.623 \\
\hline & $4(\mathrm{~S} 2)$ & 0.050 & -1.738 & & 0.146 & -2.712 \\
\hline & $5(\mathrm{~N} 2)$ & 0.179 & 0.704 & & 0.138 & 0.232 \\
\hline
\end{tabular}

* Detailed explanations can be found in Table 4 of Merritt (2004). 
numbered sequentially. Table 4 summarizes the characteristics of soil samples collected from the bald beach transect. The sediments around $\mathrm{B} 0$ and the upper part of $\mathrm{B} 1$ are mainly compacted clay. Sediments at B2-B3 and the lower part of B1 are dominated by sandy loam with gravel. Mud sediments are extensively distributed on tidal platform (B4-B7). The sediments around $\mathrm{M} 0$ are dominated by sandy loam with gravel. The sediments in the intertidal zone of the mangrove transect (M1-M8) are almost uniform (mainly mud). The soil properties along the mangrove transect is much simpler than those along the bald beach transect and therefore are not tabulated.

\section{Data analysis}

\subsection{Mangrove transect}

The quick dropping of water table at M0 during low tides indicated the presence of a high-permeability zone there. The lowest water table at M0 was even lower than that at M1. Logically this may be caused by either landward drainage or the presence of a high-permeability zone underneath the less-permeable marsh soil and the quick drainage by the sea around M0 through this zone (see the schematic illustration in Fig. 2a). However, the quick dropping of the salinity observed at M0 during lower tides also implied that there was significant freshwater recharge from inland, namely, the averaged flow direction at M0 should be seaward, which excluded the possibility of landward drainage. In the field investigation, boulders $(0.2-1.5 \mathrm{~m}$ in diameter) were exposed near the surface of M0 (Fig. 5). In addition, both hand auger drilling and big pit excavation landward of the M0 indicated that the inland area of the mangrove transect is underlain by a permeable aquifer consisting of boulders, which may extend the high-permeability zone landward and provide considerable freshwater recharge from inland.

The very slow or even negligible dropping of water table at M1-M6 during low tides was most probably due to the low-permeability of the marsh soil and the relatively flat soil surface of the mangrove marsh. Although there may exist a high-permeability zone below the marsh soil layer, it is possible that the low-permeability marsh soil and the long, flat marsh platform between M1 and M6 lead to the negligible water table dropping during low tides. The observed salinities of the deep and shallow water at M1-M6 were close to each other and did not fluctuate with time during low tides, which was in line with the almost stagnant groundwater flow in the marsh soil indicated by the constant water table near the soil surface.

During high tides, the ground surface at wells M1-M6 was submerged, and the observed salinities of deep water in these wells were close to those during the low tides. However, the salinity of shallow water in well M1 was obviously lower than those of the deep water. This is possibly because

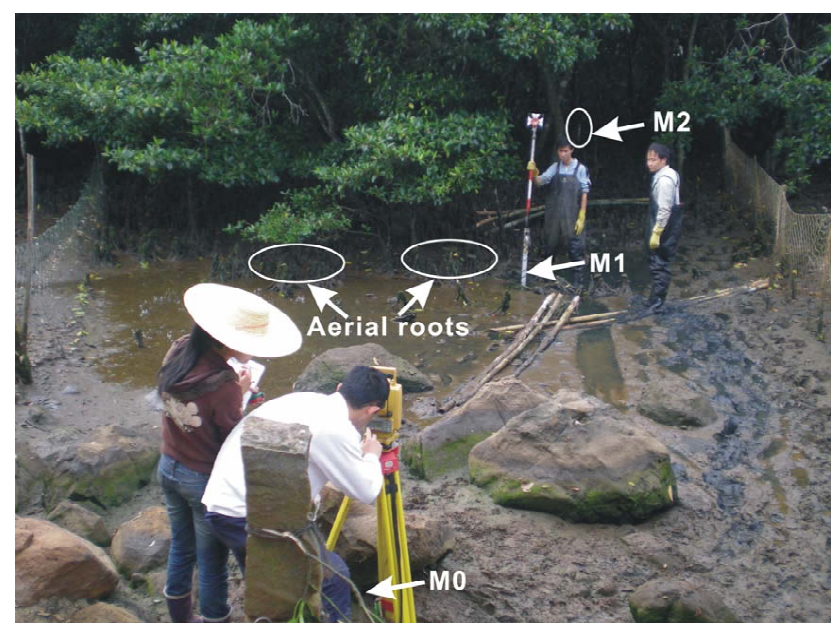

Fig. 5. Boulders $(0.2-1.5 \mathrm{~m}$ in diameter) exposed near the surface of M0 during low tides. Aerial roots, M1, and M2 are also shown.

the freshwater from M0 diluted the shallow water salinity in well M1.

The water table at M7 dropped quickly during low tides because (1) M7 is very near to the relatively steep bank and (2) the soil permeability near the tidal river bank (at least including the bottom of well M7) may be much higher than that of the inner marsh soil as illustrated in Fig. 2a (the loose bank zone (2)). The negligible dropping of water table at M8 during low tides was most probably due to the seepage face that occurred there, since the creek bed may be covered by the low-permeability mud sediments and the exit of seaward groundwater drainage from inland through the highpermeability zone underlain the marsh soil may be located near M8. This was also strongly supported by the fact that the observed salinity was significantly lower at M8 than other wells in the mangrove transect.

Note that although the salinity of the deep water $(18.6 \mathrm{ppt} \sim 25.2 \mathrm{ppt})$ at M8 is much higher than that of the shallow water ( $3.9 \mathrm{ppt} \sim 8.4 \mathrm{ppt})$ there, it is much lower than the salinity of the groundwater at M1-M7 (27 ppt 33.6 ppt) and close to that at M0 (12.9 ppt $26.1 \mathrm{ppt}$, see Fig. 4a). These observations strongly indicate that a freshwater discharge path (tube) was formed near M8 (see Fig. 2a). Many researchers have demonstrated that a fresh groundwater discharge "tube" usually forms close to the low tide mark of an intertidal zone, and separates the saltwater wedge and the landward saline plume "hanging" beneath the beach surface of the intertidal zone (Boufadel, 2000; Robinson et al., 2006; Li et al., 2008). The high-permeability of the loose bank zone (zone (2) in Fig. 2a) is beneficial to the forming of the groundwater discharge tube. The salinities of deep and shallow water at M7 were close to each other and relatively high during low tides. This implies that the freshwater discharge tube was deeper than the bottom of M7. 
Table 4. Soil characteristics along bald beach transect B-B'

\begin{tabular}{|c|c|c|c|}
\hline Well no. & Sample no. & Description & Depth form surface $(\mathrm{cm})$ \\
\hline \multirow{6}{*}{ B0 } & \multirow{6}{*}{$29-42$} & $\begin{array}{l}\text { Topsoil with recognizable } \\
\text { plant material }\end{array}$ & $0-23$ \\
\hline & & Compacted clay & $23-44$ \\
\hline & & $\begin{array}{l}\text { Compacted clay with small } \\
\text { rocks }\end{array}$ & $44-130$ \\
\hline & & Compacted clay & 130-294 \\
\hline & & Compacted clay & $294-370$ \\
\hline & & Compacted clay with silt & $370-382$ \\
\hline \multirow{4}{*}{ B1 } & \multirow{4}{*}{$\begin{array}{l}106-108 \\
\& 117-125\end{array}$} & Fine-coarse sand & $0-10$ \\
\hline & & Compacted clay & $10-180$ \\
\hline & & Sandy loam with gravel & $180-280$ \\
\hline & & Sandy loam with gravel & $280-372$ \\
\hline \multirow{3}{*}{$\mathrm{B} 2$} & \multirow{3}{*}{$1-8$} & Fine-coarse sand & $0-16$ \\
\hline & & Sandy loam & $16-24$ \\
\hline & & Sandy loam with gravel & $24-98$ \\
\hline \multirow{2}{*}{ B3 } & \multirow{2}{*}{$16-22$} & Mud with shell & $0-33$ \\
\hline & & Sandy loam & $33-156$ \\
\hline \multirow{2}{*}{ B4 } & \multirow{2}{*}{$23-28$} & Mud with shell & $0-33$ \\
\hline & & Mud & $33-158$ \\
\hline \multirow{2}{*}{ B5 } & \multirow{2}{*}{$45-50$} & Mud with shell & $0-3$ \\
\hline & & Mud & $3-154$ \\
\hline \multirow{2}{*}{ B6 } & \multirow{2}{*}{$51-56$} & Mud with shell & $0-3$ \\
\hline & & Mud & $3-153$ \\
\hline \multirow{2}{*}{ B7 } & \multirow{2}{*}{$126-131$} & Mud with shell & $0-3$ \\
\hline & & Mud & $3-167$ \\
\hline
\end{tabular}

\subsection{Bald beach transect}

The water table fluctuation at B0 was completely different from that at B1, although their spatial distance is very close (Fig. 2b). The water table at B0 fluctuated slightly with a range smaller than $0.2 \mathrm{~m}$ around the elevation of $0.25 \mathrm{~m}$. The water table at B1 fluctuated with a much greater range of about $1.4 \mathrm{~m} \sim 1.5 \mathrm{~m}$ and was always greater or equal to that at $\mathrm{B} 0$; therefore, even if there was groundwater exchange between $\mathrm{B} 0$ and $\mathrm{B} 1$, the groundwater flow direction would be landward (seawater intrusion), not seaward. This means that there should be no inland freshwater recharge in the bald beach transect. Besides, the observed salinity at B1 was high during the whole observation period (almost constant about $28 \mathrm{ppt}$ ), but the observed salinity at B0 was very low (almost constant about 5 ppt, see panel B0 and B1 of Fig. 4b). On the other hand, during high tides the water table at $\mathrm{B} 1$ was $\sim 1.4 \mathrm{~m}$ higher that at B0 (See Fig. 4b). Although the horizontal distance between B1 and B0 is small $(\sim 27 \mathrm{~m})$, such a large head difference of $1.4 \mathrm{~m}$ did not cause significant variations of the water table and salinity at B0. These observations indicated that the well B1 is located in a high-permeability zone with good hydraulic connection with the tidal water, whereas well B0 is in a much less permeable zone with very poor hydraulic connection with the tidal water. The soil properties around the two wells (Table 4) also support this conclusion. From Table 4 one can see that the sediments around B0 are mainly compacted clay, while that at B1 are dominated by sandy materials. Therefore, there was neither inland freshwater recharge during low tides nor seawater intrusion during high tides at the landward boundary of the bald beach. Otherwise, if there had been freshwater recharge from the inland, the freshwater recharge would have diluted the groundwater at B1 during low tides, so that the salinity there would have decreased, rather than remain almost constant. On the other hand, if there is freshwater recharge from inland, which equivalently means that there had been good hydraulic connection between $\mathrm{B} 0$ and $\mathrm{B} 1$, then at high tides, the seawater at B1 would have definitely enhanced the salinity at B0 significantly. 
In short, the landward side of the bald beach transect can be simplified into a no-flow boundary because this can quantitatively describe the observed significant tidal water table variations and high salinity data at B1, and also qualitatively explain the observed very low and almost constant water table and low salinity at B0. The anomaly that the observed water table elevation at $\mathrm{B} 0$ was much lower than the mean sea level $(1.181 \mathrm{~m})$ is probably due to unknown pumping of groundwater in inland area near the bald beach transect.

The observed water tables at wells B1-B3 dropped very quickly during falling tides and rose abruptly when the ground surface at the well was submerged by rising tides. The lowest water tables at B1-B3 were even much lower than that at B4, where the water table stayed near the ground surface during low tides. Due to the very poor hydraulic connection between $\mathrm{B} 0$ and $\mathrm{B} 1$, the only reasonable explanation for the quick dropping of water table at B1-B3 during low tides could be the presence of a high-permeability zone with a good hydraulic connection with the tidal creek below the mud sediment of the bald beach, a scenario similar to the mangrove transect (see Fig. 2a and b). The groundwater near B1-B3 drained quickly seaward through this highpermeability zone since the high-permeability zone outcrops in the higher intertidal zone including B1-B3. This is reasonable considering that the higher intertidal zone has much less tidal submersion periods than the middle or lower intertidal zone, causing much less silt and mud deposition the higher intertidal zone. Note that the water table at B1 was much lower than the tidal level during high tides, indicating a low-permeability zone covering the top part of B1. This was supported by the soil properties of sediments around B1 (Table 4).

The very slow or even negligible dropping of water table at B4 and B5 during low tides was most probably due to the low-permeability of the mud sediments and the relatively flat beach surface of the bald beach (see Fig. 2b). Although there may exist a high-permeability zone below the mud layer, it is possible that the low-permeability mud and the long, flat platform near B4 and B5 lead to the negligible water table dropping during low tides. The salinities at B4 and B5 were essentially constant; namely, they changed neither with time nor with depth. The water table in B6 dropped considerably lower than beach surface during low tides and rose abruptly when the beach surface was submerged by rising tide. This was most probably due to the increase of the beach slope seaward of B6 (Fig. 2b). At B7, the water table remained as high as the ground surface during low tides. Note that the surface elevation of B7 is close to that of M8. Therefore, a similar reason might lead to this negligible water table dropping: namely, seepage face might occur there due to seaward groundwater drainage of the seawater entering the outcrop of the high-permeability zone near B1, B2, and B3, and the loose bank zone similar to the mangrove transect (zone (2) in Fig. 2). During low tides, the salinities of both the deep and shallow locations at B7 remained high (about $26.5 \mathrm{ppt}$ ) and there was essentially no variation with depth. This was in great contrast with the large salinity difference between the shallow and deep locations at M8 and once again indicated that there was no inland freshwater recharge along the bald beach transect (otherwise, a freshwater discharge path near under the low tide line might dilute the salinity of shallow groundwater at B7 and resulted in large salinity difference between shallow and deep waters at B7, which is not the case).

\section{Numerical verification}

In the Introduction, we stated the following hypothesis based on the field investigations and observed water table and salinity data: the two-layered hydraulic structure of tidal marsh and inland freshwater recharge may be the main hydrogeological factors critical to mangrove development. Both the mangrove and bald beach transects have a similar macroscopical structure of two zones: a surface zone of lowpermeability mud and an underlying high-permeability zone that outcrops at the high and low tide lines. The fresh water recharge from inland is considerable along the mangrove transect but negligible along the bald beach transect. In order to verify the hypothesis, two-dimensional numerical simulations were conducted to simulate flow patterns and water balances that are consistent with the observed water tables along both transects. The salinity along the bald beach transect is assumed to be constant due to the small variation of the observed salinities in wells along that transect (Figs. 4b and 6), so the density effect and solute transport were not considered in the model. Considering the relatively significant salinity variations along the mangrove transect, great efforts were made to simulate the observed salinity variations using a two-dimensional cross-section numerical model, but the match between simulation results and the salinity measurements was poor. This was most probably due to the significant density-dependent three-dimensional flow near and within the observation wells, i.e. well effects on the groundwater flow. In order to quantify the well effects, a very fine three-dimensional mesh near each well would be necessary. However, such a great numerical effort is beyond the scope of this paper. Owing to this, here we only report the numerical simulation results that neglected the density effects related to solute transport.

Numerical simulations were conducted using the MARUN model (Boufadel et al., 1999), which can simulate solute transport in variably-saturated porous media, taking into account the effects of salt concentration on water density and water viscosity (Boufadel et al., 1999; Boufadel, 2000). The MARUN code has been verified and validated extensively (Li et al., 2008; Li and Boufadel, 2010; Xia et al., 2010; Boufadel et al., 2011). 

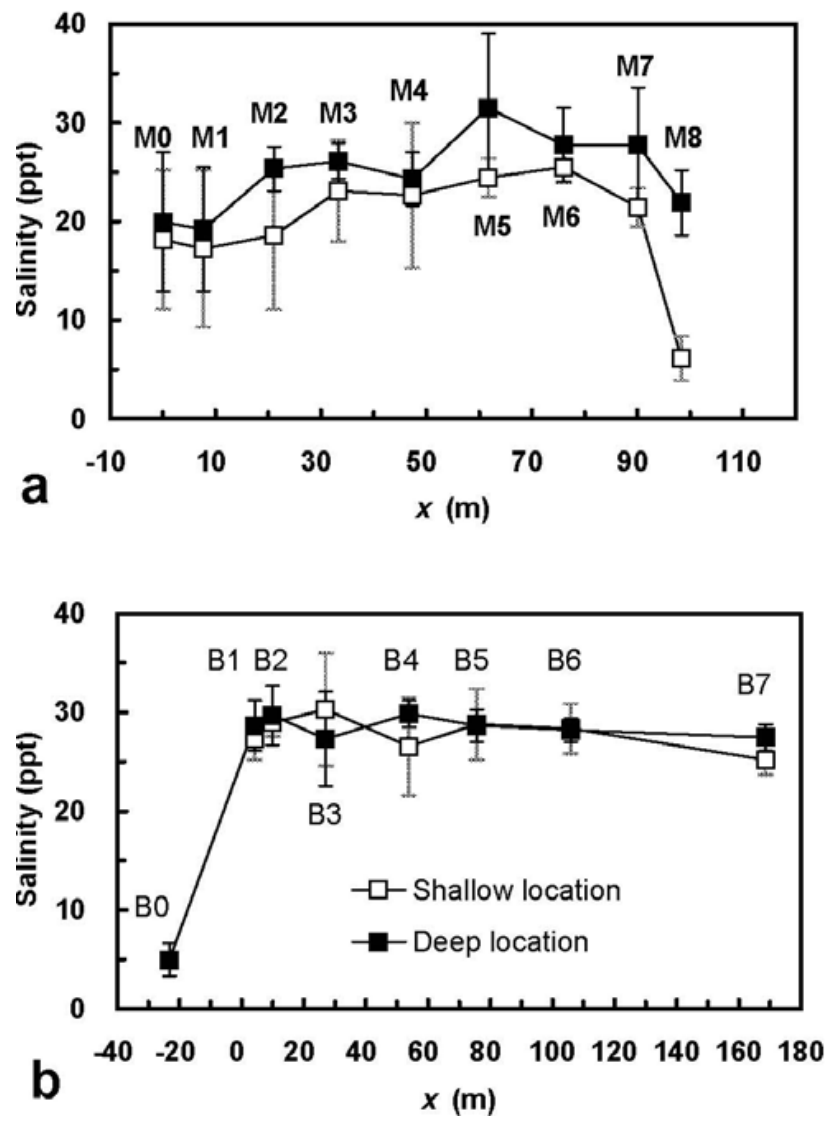

Fig. 6. Observed salinity (ppt) of groundwater over the 3-day observation period in wells along the (a) mangrove and (b) bald beach transects. The intertidal zone is located within $0 \mathrm{~m} \leq x \leq 100 \mathrm{~m}$ for the mangrove transect and $0 \mathrm{~m} \leq x \leq 190 \mathrm{~m}$ for the bald beach transect, where $x$ is the seaward distance from the high tide mark. Note that most of the observations were made during low tide.

\subsection{Simulation domain, boundary and initial conditions}

The domain for numerical simulations at each transect included the intertidal zone and part of the area below the bed of tidal river (Fig. 2). The landward boundary of the mangrove transect is vertical and located at M0, where Dirichlet boundary condition was used for the water table in the saturated zone based on interpolations of the observations at M0. The landward boundary of the bald beach transect was $10 \mathrm{~m}$ landward from the high tide line (or B2), where noflow boundary condition was used for the water table. The horizontal length of the domain was $130 \mathrm{~m}$ for the mangrove transect and $270 \mathrm{~m}$ for the bald beach transect (Fig. 2). Both domains were assumed to have an impermeable, horizontal bottom at the elevation of $-12.5 \mathrm{~m}$. Since most wells do not completely penetrate the mud zone (low-permeability zone), a hypothetical interface between the mud zone and underlain high-permeability zone was used in the numerical simulation. The depths of the interface at the wells are listed in the last column of Tables 1 and 2, and the approximate location of the interface is depicted in Fig. 2. It was also assumed that there is a thin layer of low-permeability sediments on the bed of the tidal river (Fig. 2). This low-permeability layer was identified to be $1.0 \mathrm{~m}$ thick from the river bed surface and its permeability is the same as that of the mud zone.

The types of boundary conditions on the beach surface (the upper boundary of the domain) varied with time and were updated at each time step, i.e. tidal moving boundary condition (Li and Boufadel, 2010; Xia et al., 2010). On the submerged portion of the beach surface, the water pressure was determined by the tidal seawater column above the beach surface. On the boundaries of the unsaturated zone, which included the unsaturated part of the landward boundary and the beach surface above the tidal level, no-flow boundary conditions were used. No-flow boundary conditions were also used along the domain bottom and the vertical right boundary (middle line of the tidal river). The ground water flow under the tidal bed was assumed to be symmetric with respect to the middle line of the tidal river and thus it could be regarded as a no-flow boundary. A hydrostatic pressure distribution in the domain when time is zero was used as the initial condition and then the model results were obtained after running over 100 tidal cycles.

The resolution of the mesh for both transects varied from $\sim 0.2 \mathrm{~m}$ to $\sim 0.4 \mathrm{~m}$ seaward in the $x$ direction, and from $\sim 0.3 \mathrm{~m}$ in the deep portion (depth $>5 \mathrm{~m}$ ) to $0.13 \mathrm{~m}$ in the surface portion (depth $\leq 5 \mathrm{~m}$ ) in the vertical direction. The mesh of the mangrove transect contained 41412 nodes and 81472 triangular elements, and that of the bald beach transect, 50796 nodes and 99964 triangular elements.

The method of trial and error was used to calibrate the model parameters' values such as the saturated freshwater hydraulic conductivity $(K)$, porosity, and thickness of each layer. Taking $K$ as an example, its general calibrated process could be ordered as below: firstly specify an appropriate range of $K$ for each layer, and then calibrate them together with other parameters. The $K$ values for each layer were adjusted alternatively during the calibration, and the location of the two layers' interface was also adjusted for calibration. The trial and error process was stopped when the observed data and simulated results were matched satisfactorily. The similar method of trial and error was also used in our previous studies (Guo et al., 2010; Li and Boufadel, 2010; Xia et al., 2010).

We have also conducted numerical simulations using the observed water table at $\mathrm{B} 0(x=-33 \mathrm{~m})$ as the time-changing Dirichlet boundary condition of the groundwater flow in the B transect. The results demonstrated that Dirichlet boundary condition gave almost the same results as the no-flow boundary condition, with the latter being more concise and clearer than the former in model description. This indicates an important fact: the bald beach transect has negligible freshwater recharge from inland. Thus, the type of no-flow boundary 

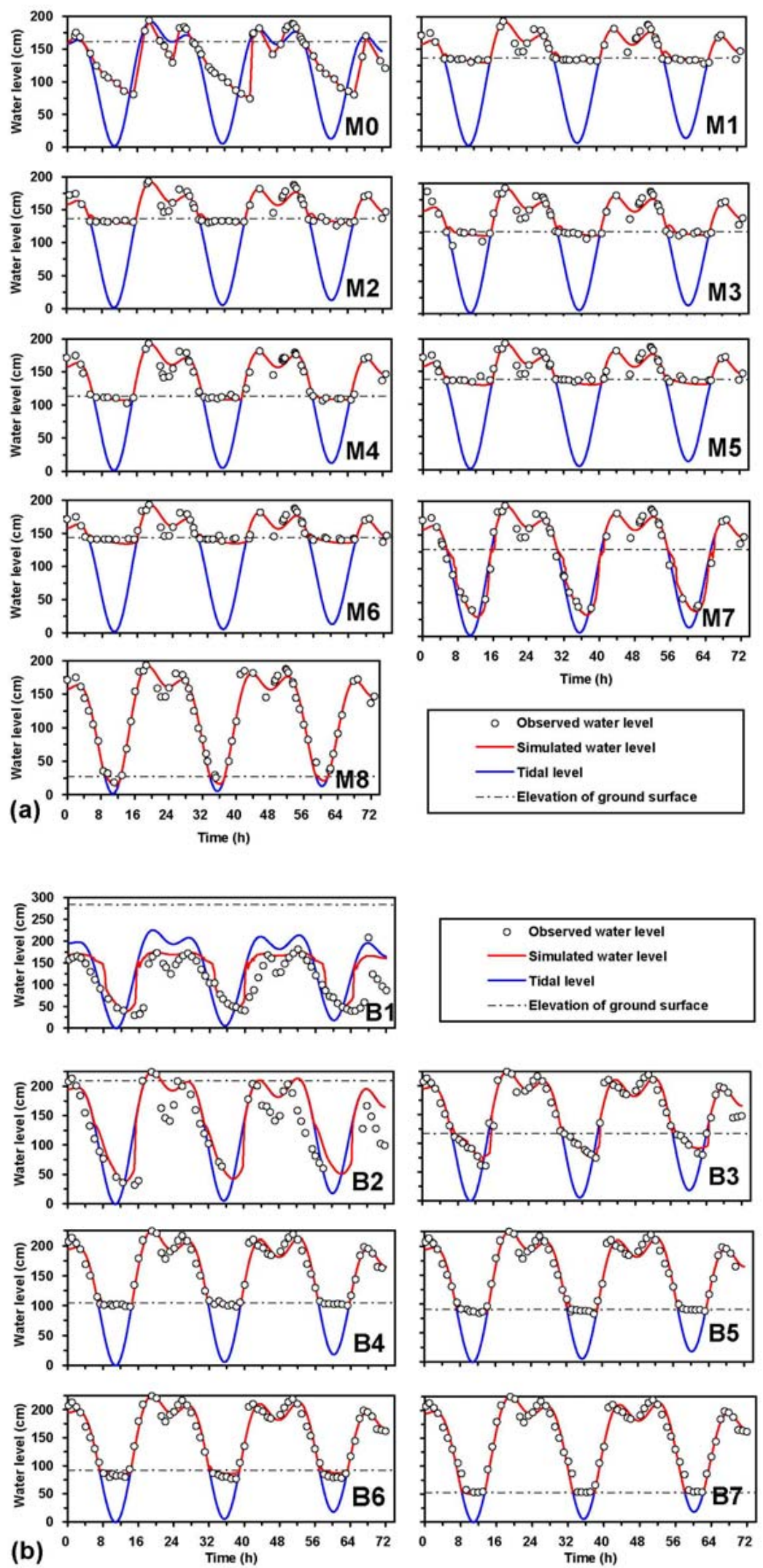

Fig. 7. Simulated (red line) and observed (circles) water levels at wells along the (a) mangrove and (b) bald beach transects. The ground surface elevation (dash dot line) at each well and the tidal level (blue line) are also shown. 


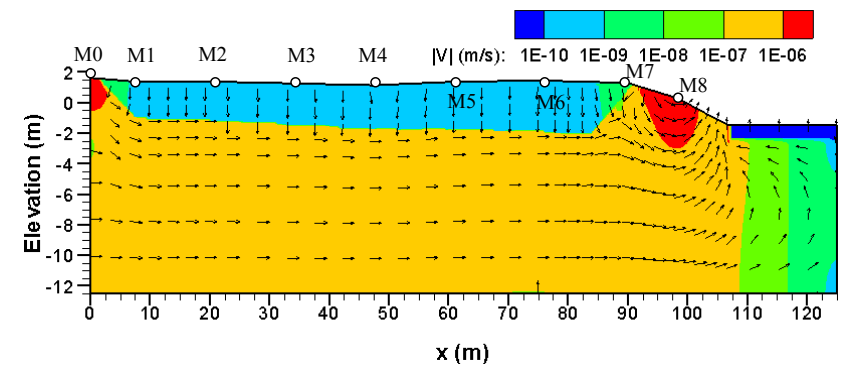

Fig. 8. Average Darcy velocity (banded colorful contours) in the mangrove transect calculated over the observation period of 3 days. Vectors with uniform length were used to indicate the velocity direction only.

condition was specified along the landward side $(x=-10 \mathrm{~m})$ of the bald beach transect.

\subsection{Results of numerical simulations}

The saturated freshwater hydraulic conductivity was found to be $1.0 \times 10^{-8} \mathrm{~m} \mathrm{~s}^{-1}$ for the mud zone and $3.0 \times 10^{-4} \mathrm{~m} \mathrm{~s}^{-1}$ for the high-permeability zone and the loose bank zone of the mangrove transect, and $5.0 \times 10^{-8} \mathrm{~m} \mathrm{~s}^{-1}$ for the mud zone and $9.0 \times 10^{-3} \mathrm{~m} \mathrm{~s}^{-1}$ for the high-permeability zone and the loose bank zone at the bald beach transect. The locations of all these zones are indicated in Fig. 2. Parameters and their values used in simulations are summarized in Table 5 .

Figure 7 shows the observed and simulated time series of water table at all wells except B0. The overall quantitative match between the observations and simulations is excellent, implying the rationality of the previous speculation of the existence of the high-permeability zone below the lowpermeability mud at both transects.

Figure 8 shows the average Darcy velocity over the 3-day observation period in the mangrove transect. The flow direction in the mud layer is mainly downward and that in the high-permeability zone is mainly seaward, illustrating that both freshwater recharge from inland and seawater from the mud layer discharged to the tidal river through the highpermeability zone. Figure 9 illustrates the transient distributions of Darcy velocity at different times along the mangrove transect. During low tides, groundwater discharged into the tidal river through the high-permeability zone, including the river bank near the low tide mark where the velocity was largest (Fig. 9a). During high tides, the high seawater level drove the groundwater to flow landward (Fig. 9b) and blocked the inland freshwater drainage exit near M8. In this case most of the inland freshwater began to discharge directly from the outcrop of the high-permeability zone near M0. All these simulation results are in line with the speculation stated in previous section, i.e. there is significant freshwater recharge from inland and the low-permeability marsh soil is underlain by a high-permeability zone in this transect.
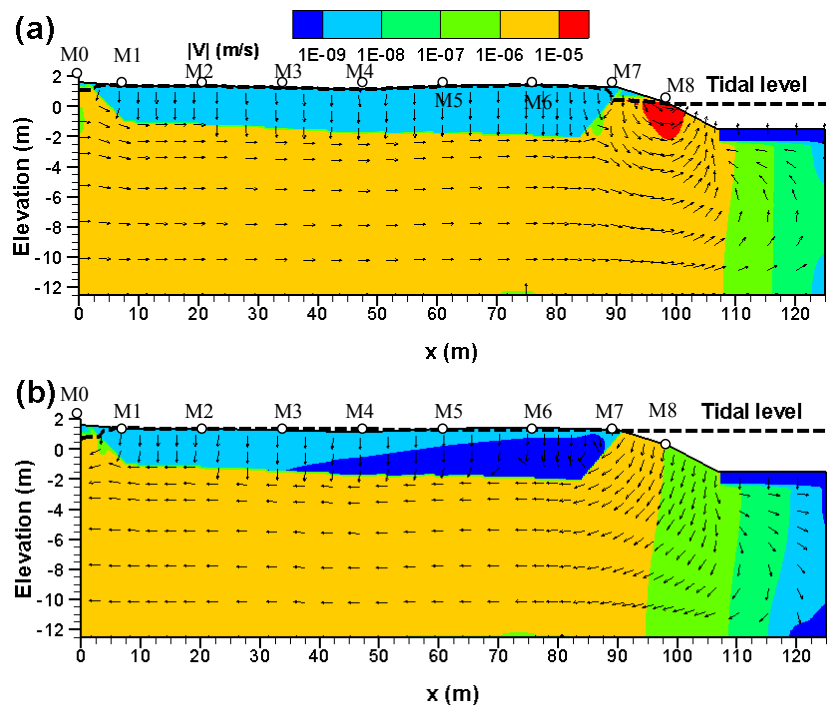

Fig. 9. Darcy velocities (banded colorful contours) in the mangrove transect $(\mathbf{a})$ at low tide (Time $=35.5 \mathrm{~h}$ ) and $(\mathbf{b})$ at high tide (Time $=41.0 \mathrm{~h}$ ). Vectors with uniform length were used to indicate the velocity direction only. The long dash line denotes water table.

Figure 10 presents the average Darcy velocity over the observation period in the bald beach transect. The pattern of time-averaged flow is similar to that in the mangrove transect (Fig. 8), except that there was no inland freshwater recharge in the bald beach transect. Note that the magnitude of the average velocity in the bald beach transect was much larger than that in the mangrove transect due to the difference of the permeability. Figure 11 depicts the distributions of Darcy velocity at low and high tides along the bald beach transect. During low tides (Fig. 11a), seawater from the outcrop of the high-permeability zone in the high intertidal zone and from the mud layer discharged to the tidal river through the high-permeability zone, which is similar to the case of the mangrove transect (Fig. 9a). During high tides, a small-scale local circulation of seawater-groundwater formed in the high intertidal zone $(-10 \mathrm{~m} \leq x \leq 20 \mathrm{~m})$ at the bald beach transect (Fig. 11b). Despite of this local circulation, the overall flow pattern in this transect was similar to that of the mangrove transect (Fig. 9b). The excellent match between the simulated and observed water tables in the bald beach transect indicated the rationality of the no-flow boundary condition used along the landward boundary of this transect, that is, the inland freshwater recharge is negligible there. These simulation results also verified the presence of a high-permeability zone underlain the less-permeable mud zone.

From a perspective of the submarine groundwater discharge (SGD) or seawater-groundwater circulation, seawater mainly infiltrates the high intertidal zone, groundwater discharges into the tidal creek near the low tide mark (Fig. 12). At mangrove transect, the simulated total outflow flux is $3.94 \mathrm{~m}^{3} \mathrm{~m}^{-1} \mathrm{~d}^{-1}$. The inland freshwater recharge 
Table 5. Model parameter values used in the numerical simulations.

\begin{tabular}{|c|c|c|c|c|}
\hline Symbol & Definition & Unit & & Value \\
\hline$\alpha$ & $\begin{array}{l}\text { Capillary fringe parameter } \\
\text { of the van Genuchten } \\
\text { (1980) model }\end{array}$ & $\mathrm{m}^{-1}$ & $\begin{array}{l}\text { Mangrove } \\
\text { Bald beach }\end{array}$ & $\begin{array}{l}0.5 \text { (mud layer) } \\
10.0 \text { (high-permeability zone) } \\
3.0 \text { (mud layer) } \\
10.0 \text { (high-permeability zone) }\end{array}$ \\
\hline$n$ & $\begin{array}{l}\text { Grain size distribution } \\
\text { parameter of the } \\
\text { van Genuchten (1980) model }\end{array}$ & - & $\begin{array}{l}\text { Mangrove } \\
\text { Bald beach }\end{array}$ & $\begin{array}{l}1.2 \text { (mud layer) } \\
5.0 \text { (high-permeability zone) } \\
1.5 \text { (mud layer) } \\
5.0 \text { (high-permeability zone) }\end{array}$ \\
\hline$K$ & $\begin{array}{l}\text { Hydraulic conductivity for } \\
\text { saturated freshwater }\end{array}$ & $\mathrm{m} \mathrm{s}^{-1}$ & $\begin{array}{l}\text { Mangrove } \\
\text { Bald beach }\end{array}$ & $\begin{array}{l}1.0 \times 10^{-8} \text { (mud layer) } \\
3.0 \times 10^{-4} \text { (high-permeability zone) } \\
5.0 \times 10^{-8} \text { (mud layer) } \\
9.0 \times 10^{-3} \text { (high-permeability zone) }\end{array}$ \\
\hline$S_{0}$ & Specific storage & $\mathrm{m}^{-1}$ & & $10^{-5}$ \\
\hline$S_{r}$ & Residual soil saturation & - & & 0.01 \\
\hline$\phi$ & Porosity & - & & 0.30 \\
\hline CONVP & $\begin{array}{l}\text { The convergence criterion of pressure } \\
\text { head in the Picard iterative scheme of } \\
\text { MARUN code }\end{array}$ & $\mathrm{m}$ & & $10^{-5}$ \\
\hline
\end{tabular}

flux was estimated to be $1.78 \mathrm{~m}^{3} \mathrm{~m}^{-1} \mathrm{~d}^{-1}$, thus tidal-induced SGD was $2.15 \mathrm{~m}^{3} \mathrm{~m}^{-1} \mathrm{~d}^{-1}$. At bald beach transect, the estimated tidal-induced SGD was $5.96 \mathrm{~m}^{3} \mathrm{~m}^{-1} \mathrm{~d}^{-1}$. Note that the seawater-groundwater circulation and SGD at both transects occurred mainly through the high-permeability zone and its outcrops at high and low intertidal zones (Figs. 2, 8, 11 and 12).

\section{Discussions}

\subsection{Comparison between the two transects}

Both transects have flat intertidal topography. The mean gradient is $1.74 \%$ for the mangrove transect and $1.4 \%$ for the bald beach transect, thus the influence of topography difference on the mangrove growth along the two transects can be excluded. Both transects were subject to the similar tidal action: similar water table variations were observed in the high, middle and lower intertidal zones. Each transect has a lowpermeability zone of mud and underlying high-permeability zone with outcrops at high and low tide lines. The seawater infiltrated the high-permeability zones mainly through their outcrops near the high intertidal zones. The groundwater in the high permeability zones discharged to the tidal river near the low tide mark. Consequently, a tide-induced seawater-groundwater circulation was formed, which is similar to those described by many previous studies ( $\mathrm{Li}$ and Jiao, 2003; Robinson et al., 2006, 2007a, b, c; Gibbes et al.,

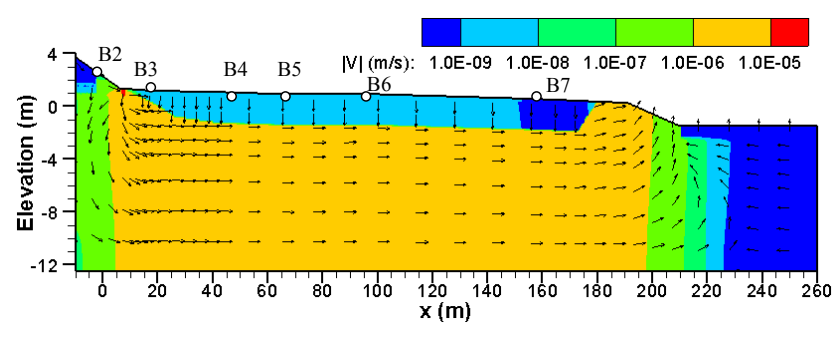

Fig. 10. Average Darcy velocity (banded colorful contours) in the bald beach transect calculated over the observation period of 3 days. Vectors with uniform length were used to indicate the velocity direction only.

2008a, b; Li et al., 2008), and qualitatively has considerable contribution to the total SGD.

Despite the similar tidal actions, seawater-groundwater circulations and spatial distributions of sediments permeability along the vertical cross sections in the intertidal zones of the two transects, the salinity distributions along the two transects showed a significant difference. Figure 6 reports the groundwater salinity over the 3-day observation period at two depths of each well in the intertidal zones of the mangrove and bald beach transects. The averaged salinity in each well along the mangrove transect (Fig. 6a) is significantly smaller than that along the bald beach transect (Fig. 6b), particularly in the high intertidal zones and near the low tide lines of the two transects. Further calculations showed that the average salinity of all the wells is $23.0 \mathrm{ppt}$ for the mangrove transect 

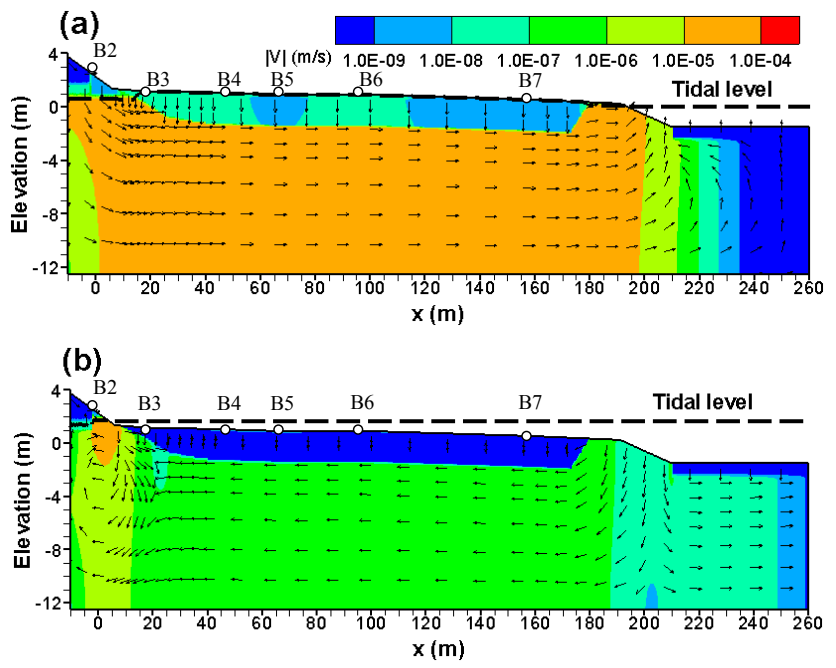

Fig. 11. Darcy velocities (banded colorful contours) in the bald beach transect (a) at low tide (Time $=35.5 \mathrm{~h}$ ) and (b) at high tide $($ Time $=41.0 \mathrm{~h})$. Vectors with uniform length were used to indicate the velocity direction only. The long dashed line denotes water table.

and $28.5 \mathrm{ppt}$ for the bald beach transect. As documented by the observations of both water table and salinity and numerical simulations of the water table, the salinity discrepancy between the two transects was most probably caused by the difference of freshwater recharge conditions between them. It may be concluded that the bald beach (not covered by mangrove plants) is due to the lack of freshwater recharge for generating a brackish beach soil condition essential to mangrove growth.

\subsection{Uncertainty analysis of the methodological approach on results}

The present study is only focusing on the hydrogeological field work and groundwater simulations in the marshes, so some uncertainties are behind the adopted methodological approach. The period of field work was conducted during the winter and was short (only three days), and there was no precipitation occurring during this period. The observed constant water table elevation was very close to the ground surface at wells M2, M3, M4, M5 and M6 during low tides, indicating that the evapotranspiration during the field work was less than the measurement error of the water table elevation. Meanwhile, the observed low salinity at several wells along the mangrove transects indicated that the effect of transpiration on the salinity was overwhelmed by the freshwater recharge. Consequently, the impact of transient variations in precipitation and transpiration on the results were ignored in our model. However, precipitation and transpiration dynamics are important processes to the water balance and salt accumulation (Bauer et al., 2006, Bauer-Gottwein et al., 2008; Chui et al., 2011), especially to the saltwater/fresh water in-
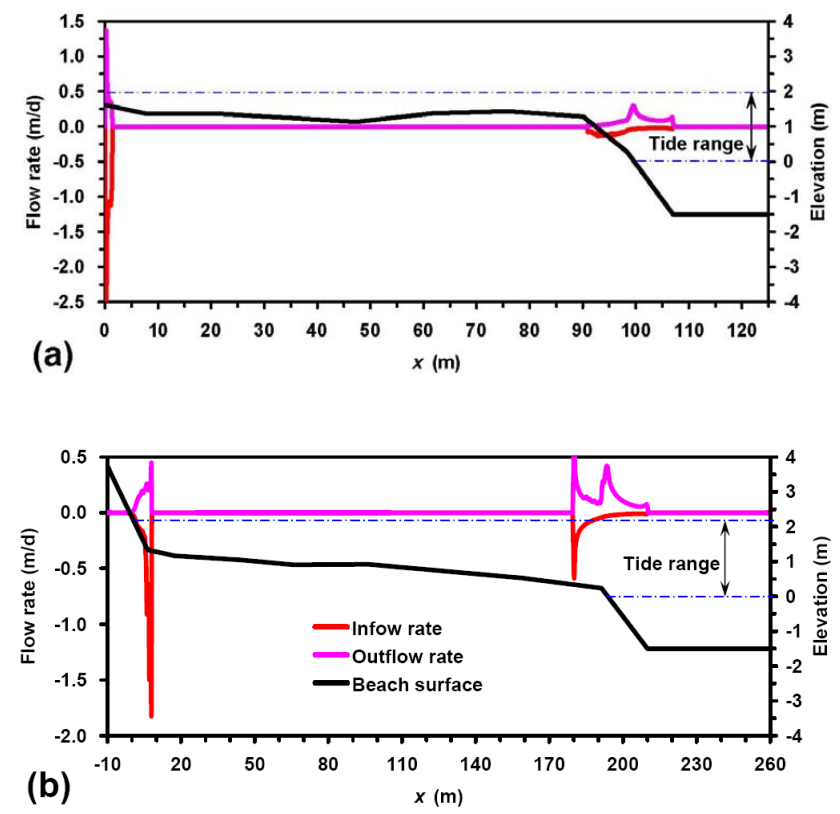

Fig. 12. Average flow rates extracted from the numerical simulations over the observation period of 3 days along (a) the mangrove and (b) the bald beach transects. Beach surface and tide range are shown to indicate the distributions of flow rate with them. Note the different scales used for each transect.

terface and dynamics. The transpiration would be significant during summer, when the presence of the vegetation tends to increase the salinity due to evapotranpiration, and thus may increase the groundwater salinity and decrease the water table. These effects of precipitation and transpiration should be considered when extending the present observed patterns of salinity and water table to other periods. The results obtained for the model that neglected the density effects are in line with the field observation, while the consequences of neglecting density flow on the modeling results should exist. Activating density flow module in the model is able to depict the effects of meteorological conditions on the fresh-salt water interface and dynamics vividly.

The tide period during the field work was spring tides; however, the water table should vary considerably during neap tides. Uncertainty occurs when using the present results to characterize the groundwater table and salinity dynamics during an entire spring-neap tide cycle. In addition, our observed water table and salinity were measured manually; employing an automated monitoring system should be an alternative way to minimize the measurement errors.

Future studies comprehensively considering the abovementioned uncertainties should provide further insights on the findings that the bald beach is due to the lack of freshwater recharge for generating a brackish beach soil condition essential to mangrove growth. 


\subsection{Ecological implications}

The salinity of the groundwater recharge into the highpermeability zone near M0 is very low (may be even fresh in deep part of M0). On the other hand, the salt through the vertical leakage of the mud zone into high-permeability zone is limited, owing to the fact that the permeability of the mud is several orders of magnitudes less than that of the high-permeability zone (Fig. 8). Therefore, the salinity of the groundwater in the whole high-permeability zone may be significantly lower than that in the mud zone. Thus, the highpermeability zone may provide opportunity for the plants in the mangrove marsh to uptake freshwater through their roots extending downward into the high-permeability zone, which may prevent the accumulation of salt in mud zone caused by plant evapotranspiration.

The mud-sand two-layered structure and seawatergroundwater circulation similar to our mangrove transect were observed in tidal marshes at other places in the world. Harvey et al. (1987) identified that subsurface groundwater in Spartina marsh, Chesapeake Bay was mainly discharged from the marsh interior toward the creek bank during exposure of the marsh surface. Yelverton and Hackney (1986) calculated that over $90 \%$ flux of groundwater was exported within $2 \mathrm{~m}$ of the creek bank to a tidal creek in a marsh of North Carolina. The numerical modeling results conducted by Gardner (2005) showed that the locus of maximum seepage flux from salt marsh sediments occurs at or near the intersection of the creek bank and the channel water surface regardless of the geomorphic configuration. Gardner (2007) explored the effects of marsh stratigraphy on the seepage of groundwater into tidal creeks by employing a two-layer structure: a sand layer (high-permeability zone) underlying the surface mud layer (low-permeability zone). He found that if the mud-sand boundary lies beneath the creek, the seepage dynamics will be the same as those of a purely mud marsh as shown by Gardner (2005), which is in line with our speculated situation shown in Fig. 2. However, if the sand layer is directly connected to the creek bottom, the increased seepage will largely emerge from the creek bottom rather than the creek bank.

We observed that the mangrove species in the lower intertidal zone (near M7) were different from those in the middle and high intertidal zones (between M1-M6). Plants in the lower intertidal zone do not have aerial roots (roots that extend upward above the ground surface for respiration), whereas plants in the middle and high intertidal zones have aerial roots (see Fig. 5). We speculate that this zonation is caused by the root respiration condition determined by the tidal groundwater hydraulics in the marsh. One notes that during low tides the water table dropped $\sim 0.9 \mathrm{~m}$ below the ground surface at $\mathrm{M} 7$, but remained near ground surface at M1-M6 (Fig. 4a). The deep dropping of water table at M7 during low tides allowed filling of the soil pores with air, which improved the root respiration condition for plants growing near the tidal river bank. Thus the plants growing near M7 do not need aerial roots. The plants growing between M1 and M6 need aerial roots since their rhizosphere is always saturated, thereby preventing the normal root respiration. In addition, the plant stem density (number of culms per squared meter) was higher near the tidal river bank than in the middle and high intertidal zone, a pattern similar to that reported by Mendelssohn et al. (1981) and Dacey and Howes (1984) that some salt marsh plant species grow better near tidal creeks than in the inner marsh areas. The impacts of root respiration condition on the plant growing status in tidal marshes have been discussed by many researchers (Ursino et al., 2004; Li et al., 2005; Marani et al., 2005, 2006; Wilson and Gardner, 2005; Gardner, 2009; Tossatto et al., 2009). Li et al. (2005) demonstrated that the optimal plant root aeration condition in a homogeneous tidal marsh transect always occurs near the tidal creek, which may explain the previous observations of Mendelssohn et al. (1981) and Dacey and Howes (1984). Our water table observation along the mangrove transect again indicated that plant root aeration condition is better near the tidal river bank (M7) than in the inner marsh areas (M1-M6), and is influenced not only by the topography, but also by the soil heterogeneity (the hydraulic conductivity of the soil near M7 is several orders of magnitude greater than that in the inner marsh areas between M1 and M6).

Owing to the importance of inland groundwater on the mangrove marshes revealed in this paper, preventing the inland groundwater from pollution and relieving the influence of land-oriented contaminants on the mangrove marshes will offer effective protection for coastal mangrove forests. On the other hand, observations from many spill events around the world have shown that mangroves have been severely impacted by oil exposures (Krebs and Burns, 1977; Jackson et al., 1989; Tam et al., 2005), and they are particularly difficult to protect and clean up once a spill has occurred because they are physically intricate and relatively hard to access. In the present study, a loose bank zone was found on both transects, which improves the plant root aeration condition near the tidal river bank. However, this loose bank zone possibly also provides preferential path for spilled oil to enter the marshes and inversely block the root soil aeration. All these findings may provide new insights into the management and restoration of these types of coastal ecological systems. There are many mangrove systems in the world that are similar to Dongzhaigang. Such examples include tidal marshes in New England (Howes et al., 1996), in Gazi Bay in Kenya (Kitheka, 1996), in Inhaca Island in Mozambique (Hoguane et al., 1999), and in north Brazil (Schwendenmann et al., 2006). The model described here may apply in these tidal marsh systems. 


\section{Summary and conclusions}

In summary, this study showed that

1. the importance of freshwater to tidal marsh ecological systems is confirmed by quantitatively correlating water levels and salinity profiles from two transects in Dongzhaigang mangrove marsh. Both the observed water tables and salinities at wells in inland and high intertidal zone indicated no inland freshwater recharge into the bald beach transect. Salinity observations and numerical simulations demonstrated that significant freshwater recharge occurred in the mangrove transect.

2. The two transects investigated here were found to have a mud-sand two-layered structure: a surface zone of lowpermeability mud and an underlying high-permeability zone that outcrops at the high and low tide lines. The mud-sand two-layered structure plays a key role in the hydrological regime of the study areas. It is indicated that seawater infiltrates the high-permeability zone through its outcrop near the high intertidal zone, and discharges from the tidal river bank in the vicinity of the low tide line.

3. We quantitatively investigated the groundwaterseawater circulation dominated by the highpermeability zone of mud-sand structure tidal marsh, which provides considerable contribution to the total submarine groundwater discharge (SGD).

4. To our knowledge, our work is the first paper to present the field data of groundwater flow and salinity in mangroves in China.

5. The last and most important aspect is the ecological implications arising from our study. this study suggests that the bald beach is most probably due to the lack of freshwater recharge for generating brackish conditions that result from mixing of seawater with freshwater, because the mangroves would not survive in pure freshwater and high-salinity saltwater conditions. The existence of the high-permeability zone is a critical factor for the mangrove development, because the high-permeability zone may provide opportunity for the plants in the mangrove marsh to uptake freshwater and oxygen through their roots extending downward into the high-permeability zone, which may help limit the buildup of salt in the root zone caused by evapotranspiration and enhance salt removal, which may further increase the production of marsh grasses and influence their spatial distribution.

Finally, there are many issues that have not been considered here but should be examined urgently. These include, e.g. the long-term observations of precipitation, evapotranspiration, groundwater salinity and water table variations along the mangrove transect, the quantifications and modeling of ecohydrological feedback mechanisms based on these observations (e.g. Bauer et al., 2006; Bauer-Gottwein et al. 2008), and the effects of the mixing and diffusion of solute inside the observation well on the groundwater flow that are essentially three-dimensional or at least locally radial, i.e. the well effects on the density-dependent groundwater flow near and within the observation wells.

Acknowledgements. This research is supported by the National Natural Science Foundation of China (NSFC, No. 40672167), NSFC Outstanding Young Scientist Grant (No. 41025009), and the 111 Project (B08030). We are grateful to Zhiming Han (Hainan Geo-Environment Monitoring Institute) for his help for the fieldwork. The fieldwork was completed with the assistance from many project team members including Shuang Liu from Anshan Normal University, Xiaolong Geng from Temple University, Yuchen Zhang, Fangxuan He, and Li Wang from Liaoning Normal University, Shi Chen from China Coal Research Institute, Ye Tian, Chao Liu, Guohui Li, and Ying Yang from China University of Geosciences (Wuhan), Pingping Sun from China Geological Survey, and Qiaona Guo from Hohai University. We gratefully acknowledge Thomas Graf, Peter Bauer-Gottwein and Arnaut van Loon, whose comments contributed to significant improvements in the manuscript, and we thank Harrie-Jan Hendricks Franssen for handling our manuscript.

Edited by: H.-J. Hendricks Franssen

\section{References}

Akamatsu, Y., Ikeda, S., and Toda, Y.: Transport of nutrients and organic matter in a mangrove swamp, Estuar. Coast. Shelf S., 82, 233-242, 2009.

Alber, M., Swenson, E. M., Adamowicz, S. C., and Mendelssohn, I. A.: Salt marsh dieback: An overview of recent events in the US, Estuar. Coast. Shelf S., 80, 1-11, 2008.

Bauer-Gottwein, P., Held, R. J., Zimmermann, S., Linn F., and Kinzelbach W.: Coupled flow and salinity transport modelling in semi-arid environments: The Shashe River Valley, Botswana, J. Hydrol., 316, 163-183, 2006.

Bauer-Gottwein, P., Rasmussen, N. F., Feificova, D., and Trapp, S.: Phytotoxicity of salt and plant salt uptake: Modeling ecohydrological feedback mechanisms, Water Resour. Res., 44, W04418, doi:10.1029/2007WR006067, 2008.

Bosire, J. O., Dahdouh-Guebas, F., Walton, M., Crona, B. I., Lewis, R. R., Field, C., Kairo, J. G., and Koedam, N.: Functionality of restored mangroves: A review, Aquat. Bot., 89, 251-259, 2008.

Boufadel, M. C.: A mechanistic study of nonlinear solute transport in a groundwater-surface water system under steady state and transient hydraulic conditions, Water Resour. Res., 36, 25492565, 2000.

Boufadel, M. C., Suidan, M. T., and Venosa, A. D.: A numerical model for density-and-viscosity-dependent flows in twodimensional variably saturated porous media, J. Contam. Hydrol., 37, 1-20, 1999.

Boufadel, M. C., Xia, Y. Q., and Li, H. L.: Modeling solute transport and transient seepage in a laboratory beach under tidal influence, Environ. Modell. Softw., 26, 899-912, 2011. 
Chapman, V. J.: Studies in salt marsh ecology: sections i to iii, J. Ecol., 26, 144-179, 1938.

Chapman, V. J.: Studies in salt marsh ecology: sections vi to vii, J. Ecol., 28, 118-152, 1940.

Chapman, V. J.: Wet Coastal Ecosystem, Eslevier Scientific Publishing Company, Amsterdam, 1977.

Chui T. F. M., Low, S. Y., and Liong, S. Y.: An ecohydrological model for studying groundwater-vegetation interactions in wetlands, J. Hydrol., 409, 291-304, 2011.

Clarke, L. D. and Hannon, N. J.: The mangrove swamp and salt marsh communities of the Sydney District: III. Plant growth in relation to salinity and waterlogging, J. Ecol., 58, 351-369, 1970.

Dacey, J. W. H. and Howes, B. L.: Water uptake controls water table movement and sediment oxidation in short spartina marsh, Science, 224, 487-489, 1984.

Dittmar, T., Hertkorn, N., Kattner, G., and Lara, R. J.: Mangroves, a major source of dissolved organic carbon to the oceans, Global Biogeochem. Cy., 20, Gb1012, doi:10.1029/2005GB002570, 2006.

Duke, N. C., Ball, M. C., and Ellison, J. C.: Factors influencing biodiversity and distributional gradients in mangroves, Global Ecol. Biogeogr., 7, 27-47, 1998.

Duke, N. C., Meynecke, J. O., Dittmann, S., Ellison, A. M., Anger, K., Berger, U., Cannicci, S., Diele, K., Ewel, K. C., Field, C. D., Koedam, N., Lee, S. Y., Marchand, C., Nordhaus, I., and Dahdouh-Guebas, F.: A world without mangroves, Science, 317, 41-42, 2007.

Field, C. B., Osborn, J. G., Hoffman, L. L., Polsenberg, J. F., Ackerly, D. D., Berry, J. A., Bjorkman, O., Held, A., Matson, P. A., and Mooney, H. A.: Mangrove biodiversity and ecosystem function, Global Ecol. Biogeogr., 7, 3-14, 1998.

Fu, G. A.: The mangroves of Dongzhai Gang Natural Reserve, Hainan, Guihaia, 15, 340-346, 1995 (in Chinese).

Gardner, L. R.: Role of geomorphic and hydraulic parameters in governing pore water seepage from salt marsh sediments, Water Resour. Res., 41, W07010, doi:10.1029/2004WR003671, 2005.

Gardner, L. R.: Role of stratigraphy in governing pore water seepage from salt marsh sediments, Water Resour. Res., 43, W07502, doi:10.1029/2006WR005338, 2007.

Gardner, L. R.: Comment on "Spatial organization and ecohydrological interactions in oxygen-limited vegetation ecosystems" by Marco Marani et al., Water Resour. Res., 45, W05603, doi:10.1029/2007WR006165, 2009.

Gardner, L. R. and Porter, D. E.: Stratigraphy and geologic history of a southeastern salt marsh basin, North Inlet, South Carolina, USA, Wetl. Ecol. Manag., 9, 371-385, 2001.

Gibbes, B., Robinson, C., Carey, H., Li, L., and Lockington, D.: Tidally driven pore water exchange in offshore intertidal sandbanks: Part I. Field measurements, Estuar. Coast. Shelf S., 79, 121-132, 2008a.

Gibbes, B., Robinson, C., Li, L., Lockington, D., and Li, H. L.: Tidally driven pore water exchange within offshore intertidal sandbanks: Part II numerical simulations, Estuar. Coast. Shelf S., 80, 472-482, 2008b.

Gilman, E. L., Ellison, J., Duke, N. C., and Field, C.: Threats to mangroves from climate change and adaptation options: A review, Aquat. Bot., 89, 237-250, 2008.

Guo, H. P., Jiao, J. J., and Li, H. L.: Groundwater response to tidal fluctuation in a two-zone aquifer, J. Hydrol., 381, 364-371, 2010.
Guo, Q. N., Li, H. L., Boufadel, M. C., and Sharifi, Y.: Hydrodynamics in a gravel beach and its impact on the Exxon Valdez oil, J. Geophys. Res., 115, C12077, doi:10.1029/2010JC006169, 2010.

Harvey, J. W., Germann, P. F., and Odum, W. E.: Geomorphological control of subsurface hydrology in the creekbank zone of tidal marshes, Estuar. Coast. Shelf S., 25, 677-691, 1987.

Hemond, H. F. and Fifield, J. L.: Subsurface flow in a salt marsh peat, Limnol. Oceanogr., 27, 126-136, 1982.

Hoguane, A. M., Hill, A. E., Simpson, J. H., and Bowers, D. G.: Diurnal and tidal variation of temperature and salinity in the Ponta Rasa Mangrove swamp, Mozambique, Estuar. Coast. Shelf S., 49, 251-264, 1999.

Howes, B. L., Weiske, P. K., Goehringer, D. D., and Teal., J. M.: Interception of freshwater and nitrogen transport from uplands to coastal waters: the role of saltmarshes, in: Estuarine Shores: Hydrological, Geomorphological and Ecological Interactions, edited by: Nordstrom, K. and Roman, C., Wiley Interscience, Sussex, England, 287-310, 1996.

Hughes, C. E., Binning, P., and Willgoose, G. R.: Characterisation of the hydrology of an estuarine wetland, J. Hydrol., 211, 34-49, 1998.

Jackson, J. B. C., Cubit, J. D., Keller, B. D., Batista, V., Burns, K., Caffey, H. M., Caldwell, R. L., Garrity, S. D., Getter, C. D., Gonzalez, C., Guzman, H. M., Kaufmann, K. W., Knap, A. H., Levings, S. C., Marshall, M. J., Steger, R., Thompson, R. C., and Weil, E.: Ecological Effects of a Major Oil Spill on Panamanian Coastal Marine Communities, Science, 243, 37-44, 1989.

Kitheka, J. U.: Water circulation and coastal trapping of brackish water in a tropical mangrove-dominated bay in Kenya, Limnol. Oceanogr., 41, 169-176, 1996.

Kjerfve, B.: Manual for investigation of hydrological processes in mangrove ecosystems, UNESCO/UNDP Project, Research and its Application to the Management of the Mangroves of Asia and the Pacific (RAS/86/120), 1990.

Krauss, K. W., Lovelock, C. E., McKee, K. L., Lopez-Hoffman, L., Ewe, S. M. L., and Sousa, W. P.: Environmental drivers in mangrove establishment and early development: A review, Aquat. Bot., 89, 105-127, 2008.

Krebs, C. T. and Burns, K. A.: Long-term effects of an oil spill on populations of the salt-marsh crab uca pugnax, Science, 197, 484-487, 1977.

Kristensen, E., Bouillon, S., Dittmar, T., and Marchand, C.: Organic carbon dynamics in mangrove ecosystems: A review, Aquat. Bot., 89, 201-219, 2008.

Li, H. L. and Boufadel, M. C.: Long-term persistence of oil from the Exxon Valdez spill in two-layer beaches, Nat. Geosci., 3, 96-99, 2010.

Li, H. L. and Jiao, J. J.: Tide-induced seawater-groundwater circulation in a multi-layered coastal leaky aquifer system, J. Hydrol., 274, 211-224, 2003.

Li, H. L., Li, L., and Lockington, D.: Aeration for plant root respiration in a tidal marsh, Water Resour. Res., 41, W06023, doi:10.1029/2004WR003759, 2005.

Li, H. L., Boufadel, M. C., and Weaver, J. W.: Tide-induced seawater-groundwater circulation in shallow beach aquifers, J. Hydrol., 352, 211-224, 2008.

Liu, J. G. and Diamond, J.: China's environment in a globalizing world, Nature, 435, 1179-1186, 2005. 
Lugo, A. E. and Snedaker, S. C.: The ecology of mangroves, Annual Review of Ecology, Evolution, and Systematics (formerly, Annu. Rev. Ecol. Syst.), 5, 39-64, 1974.

Luther, G. W., III, Church, T. M., Scudlark, J. R., and Cosman, M.: Inorganic and organic sulfur cycling in salt-marsh pore waters, Science, 232, 746-749, 1986.

Marani, M., Ursino, N., and Silvestri, S.: Reply to comment by Alicia M. Wilson and Leonard Robert Gardner on "Subsurface flow and vegetation patterns in tidal environments", Water Resour. Res., 41, W07022, doi:10.1029/2004WR003722, 2005.

Marani, M., Silvestri, S., Belluco, E., Ursino, N., Comerlati, A., Tosatto, O., and Putti, M.: Spatial organization and ecohydrological interactions in oxygen-limited vegetation ecosystems, Water Resour. Res., 42, W06D06, doi:10.1029/2005WR004582, 2006.

Mendelssohn, I. A., McKee, K. L., and Patrick, W. H.: Oxygen deficiency in Spartina alterniflora roots: Metabolic adaptation to anoxia, Science, 214, 439-441, 1981.

Merritt, M. L.: Estimating hydraulic properties of the Floridian aquifer sytem by analysis of earth-tide, ocean-tide, and barometric effects, Collier and Hendry Counties, Florida, Tallahassee, Florida, 69, 2004.

Montalto, F. A., Steenhuis, T. S., and Parlange, J. Y.: The hydrology of Piermont Marsh, a reference for tidal marsh restoration in the Hudson river estuary, New York, J. Hydrol., 316, 108-128, 2006.

Nagelkerken, I., Blaber, S. J. M., Bouillon, S., Green, P., Haywood, M., Kirton, L. G., Meynecke, J. O., Pawlik, J., Penrose, H. M., Sasekumar, A., and Somerfield, P. J.: The habitat function of mangroves for terrestrial and marine fauna: A review, Aquat. Bot., 89, 155-185, 2008.

Nuttle, W. K. and Harvey, J. W.: Fluxes of water and solute in a coastal wetland sediment. 1 . The contribution of regional groundwater discharge, J. Hydrol., 164, 89-107, 1995.

Pennings, S. C. and Callaway, R. M.: Salt marsh plant zonation: The relative importance of competition and physical factors, Ecology, 73, 681-690, 1992.

Robinson, C., Gibbes, B., and Li, L.: Driving mechanisms for groundwater flow and salt transport in a subterranean estuary, Geophys. Res. Lett., 33, L03402, doi:10.1029/2005GL025247, 2006.

Robinson, C., Gibbes, B., Carey, H., and Li, L.: Salt-freshwater dynamics in a subterranean estuary over a spring-neap tidal cycle, J. Geophys. Res., 112, C09007, doi:10.1029/2006JC003888, 2007a.

Robinson, C., Li, L., and Barry, D. A.: Effect of tidal forcing on a subterranean estuary, Adv. Water Resour., 30, 851-865, $2007 \mathrm{~b}$.

Robinson, C., Li, L., and Prommer, H.: Tide-induced recirculation across the aquifer-ocean interface, Water Resour. Res., 43, W07428, doi:10.1029/2006WR005679, 2007c.

Schwendenmann, L., Riecke, R., and Lara, R.: Solute dynamics in a North Brazilian mangrove: the influence of sediment permeability and freshwater input, Wetl. Ecol. Manag., 14, 463-475, 2006.
Selvam, V.: Environmental classification of mangrove wetlands of India, Curr. Sci., 84, 757-765, 2003.

Silvestri, S., Defina, A., and Marani, M.: Tidal regime, salinity and salt marsh plant zonation, Estuar. Coast. Shelf S., 62, 119-130, 2005.

Spalding, M., Blasco, F., and Field, C.: World mangrove atlas, International Society for Mangrove Ecosystems, Japan: Okinawa, 178 pp., 1997.

Steudler, P. A. and Peterson, B. J.: Contribution of gaseous sulphur from salt marshes to the global sulphur cycle, Nature, 311, 455457, 1984.

Tam, N. F. Y., Wong, T. W. Y., and Wong, Y. S.: A case study on fuel oil contamination in a mangrove swamp in Hong Kong, Mar. Pollut. Bull., 51, 1092-1100, 2005.

Tide table: http://www.coi.gov.cn, last access: 2 September 2007.

Tossatto, O., Belluco, E., Silvestri, S., Ursino, N., Comerlati, A., Putti, M., and Marani, M.: Reply to comment by L. R. Gardner on "Spatial organization and ecohydrological interactions in oxygen-limited vegetation ecosystems", Water Resour. Res., 45, W05604, doi:10.1029/2007WR006345, 2009.

Ursino, N., Silvestri, S., and Marani, M.: Subsurface flow and vegetation patterns in tidal environments, Water Resour. Res., 40, W05115, doi:10.1029/2003WR002702, 2004.

Valiela, I. and Teal, J. M.: The nitrogen budget of a salt marsh ecosystem, Nature, 280, 652-656, 1979.

Valiela, I., Bowen, J. L., and York, J. K.: Mangrove forests: One of the world's threatened major tropical environments, Bioscience, 51, 807-815, 2001.

Wilson, A. M. and Gardner, L. R.: Comment on "Subsurface flow and vegetation patterns in tidal environments" by Nadia Ursino, Sonia Silvestri, and Marco Marani, Water Resour. Res., 41, W07021, doi:10.1029/2004WR003554, 2005.

Wilson, A. M. and Gardner, L. R.: Tidally driven groundwater flow and solute exchange in a marsh: Numerical simulations, Water Resour. Res., 42, W01405, doi:10.1029/2005WR004302, 2006.

Woodroffe, C. D., Thom, B. G., and Chappell, J.: Development of widespread mangrove swamps in mid-Holocene times in northern Australia, Nature, 317, 711-713, 1985.

Xia, Y. Q., Li, H. L., Boufadel, M. C., and Sharifi, Y.: Hydrodynamic factors affecting the persistence of the Exxon Valdez oil in a shallow bedrock beach, Water Resour. Res., 46, W10528, doi:10.1029/2010WR009179, 2010.

Xin, P., Jin, G., Li, L., and Barry, D. A.: Effects of crab burrows on pore water flows in salt marshes, Adv. Water Resour., 32, 439449, 2009.

Ye, Y. and Lu, C.: Dynamics of $\mathrm{CH} 4$ in soil under Aegiceras Corniculatum mangrove at Changning estuary of Hainan Island, Journal of Tropical Oceanography, 20, 35-42, 2001 (in Chinese).

Yelverton, G. F. and Hackney, C. T.: Flux of dissolved organic carbon and pore water through the substrate of a Spartina alterniflora marsh in North Carolina, Estuar. Coast. Shelf S., 22, 255-267, 1986. 